\title{
Effects of Combined Application of Potassium Silicate and Salicylic Acid on the Defense Response of Hydroponically Grown Tomato Plants to Ralstonia solanacearum Infection
}

\author{
Ni-Hao Jiang ${ }^{1, *}$ and Shi-Han Zhang ${ }^{2}$ \\ 1 School of Resources, Environment and Chemistry, Chuxiong Normal University, Chuxiong 675000, China \\ 2 School of Education, Chuxiong Normal University, Chuxiong 675000, China; zsh1993@cxtc.edu.cn \\ * Correspondence: jnhskip@cxtc.edu.cn; Tel.: +86-0878-310-0525
}

Citation: Jiang, N.-H.; Zhang, S.-H. Effects of Combined Application of Potassium Silicate and Salicylic Acid on the Defense Response of Hydroponically Grown Tomato Plants to Ralstonia solanacearum Infection. Sustainability 2021, 13, 3750 https://doi.org/10.3390/su13073750

Academic Editors: Spyridon

A. Petropoulos and Nikos Tzortzakis

Received: 10 February 2021

Accepted: 25 March 2021

Published: 27 March 2021

Publisher's Note: MDPI stays neutral with regard to jurisdictional claims in published maps and institutional affiliations.

Copyright: (c) 2021 by the authors Licensee MDPI, Basel, Switzerland. This article is an open access article distributed under the terms and conditions of the Creative Commons Attribution (CC BY) license (https:// creativecommons.org/licenses/by/ $4.0 /)$.

\begin{abstract}
Bacterial wilt, caused by soilborne pathogenic bacterium Ralstonia solanacearum, is a serious and widespread disease that affects global tomato production. Both silicon (Si) and salicylic acid (SA) play important roles in enhancing tomato resistance against bacterial wilt, however, their combined effects on the defense responses of infected tomato plants remain unknown. Hence, the combined effects of Si and SA on physiological and biochemical parameters of $R$. solanacearum-infected tomato plants were investigated. The combination treatment of $\mathrm{Si}$ and SA significantly decreased disease incidences, lipoxygenase (LOX) activity and ethylene (ET) production. The combined treatments were more prominent in improving the morphological traits of root systems, such as root length, root surface area, average root diameter and root volume. The activities of polyphenol oxidase (PPO) and peroxidase (POD) and the concentrations of total soluble phenolics (TSPs) and lignin-thioglycolic acid (LTGA) derivatives were significantly increased in the plants with combined treatments. Si in combination with SA could significantly enhance neutral invertase (NI) and acid invertases (AI) activities in the leaves of tomato plants at 3 days post-infection (dpi) compared with application of Si alone. Three defense-related genes, PAL, POD and pathogenesis-related protein 1 (PR1), were significantly induced in $\mathrm{Si}+\mathrm{SA}$ treatment at $7 \mathrm{dpi}$ when compared with individual application of $\mathrm{Si}$ or SA. The expression level of salicylic acid-binding protein 2 (SABP2) was significantly higher for combination treatment when compared with treatment of Si or SA alone. The possible mechanisms involved in the synergistic effects of Si and SA on the control of tomato bacterial wilt were proposed. This study indicates that under hypertonic conditions, the combined application of $2.0 \mathrm{mM}$ potassium silicate $\left(\mathrm{K}_{2} \mathrm{SiO}_{3}\right)$ and $0.5 \mathrm{mM} \mathrm{SA}$ had a synergistic effect on the control of tomato bacterial wilt.
\end{abstract}

Keywords: tomato (Solanum lycopersicum); silicon; salicylic acid; Ralstonia solanacearum; induced resistance

\section{Introduction}

Tomato (Solanum lycopersicum) is one of the most economically important vegetable crops in the world [1]. Bacterial wilt, which is caused by the soilborne pathogenic bacterium Ralstonia solanacearum, is a serious and widespread disease that affects tomato production throughout the world [2-4]. R. solanacearum typically invades plants through the root wounds, colonizes host plant xylem vessels, and causes yield losses for 35-90\% [5]. Bacterial wilt is managed with synthetic fungicides and by breeding resistant cultivars [6-9]. However, breeding for stable and durable bacterial wilt resistance is a daunting task due to the high degree of genetic diversity and pathogenic variability of $R$. solanacearum [6-8]. Application of chemical agents has been the main strategy for bacterial wilt control, but it may have negative environmental consequences and/or pose risk to humans [6-8]. Therefore, an environment-friendly alternative strategy for bacterial wilt management needs to be developed. 
Silicon (Si) is the second most abundant mineral element in soil and comprises approximately $28 \%$ of the earth's crust $[10,11]$. Increasing numbers of reports have adequately documented the beneficial effects of silicon in enhancing the disease resistance of plants to several pathogens, but the exact mechanisms underlying this phenomenon remain controversial $[4,9,12,13]$. Some studies suggest that the enhanced resistance to disease in Si-accumulating plants has been linked with mechanical barriers, due to accumulation and polymerization of $\mathrm{Si}$ in different organs and limited pathogen penetration and invasion $[8,9,12-15]$. Studies also showed that Si may play a more active role in enhancing plant resistance to pathogen infection by activating the defence responses in the host, including the production of defence proteins, antimicrobial compounds [16-18]. Several recent studies have found that silicon could influence the expression of defense-related genes and the levels of endogenous hormones [9,12,19-21]. The exact mechanism of Si in enhancing plant disease resistance still requires a thorough investigation.

In tomato, a number of reports have shown that $\mathrm{Si}$ suppresses bacterial wilt disease caused by R. solanacearum, and Si addition to tomato plants can be used as environmentally friendly alternatives to suppress bacterial wilt $[3,4,8-10]$. Several studies have demonstrated $[9,22]$ the induction effect of silicon on the activity of defense-related enzymes, such as peroxidase (POD), polyphenol oxidase (PPO), lipoxygenase (LOX) and phenylalanine ammonia lyase (PAL) in tomato plants challenged with $R$. solanacearum infection. A recent study showed that the expression of ethylene (ET) and jasmonic acid (JA) dependent genes (JERF3, TSRF1 and ACCO) was induced by exogenous $\mathrm{Si}$ in the soil culture system, and suggested that ET and JA pathways may participate in Si-induced tomato bacterial wilt resistance, but the authors have not ruled out a role of salicylic acid (SA) [8]. Recently, our group reported that Si-modulated phenolic compound metabolism in roots or root exudates, and that $\mathrm{Si}$ could significantly influence soil microbial community component in rhizosphere soil of Si-treated tomato plants infected with $R$. solanacearum [23,24]. To date, despite an increase in researches on the underlying mechanism of Si-induced tomato resistance against $R$. solanacearum, the exact mechanism still remains enigmatic $[9,12,23,25]$. Currently, limited mechanism investigation mainly focuses on the stems' responses to $R$. solanacearum $[8,9,23,25]$. However, the fact is that $R$. solanacearum naturally infects plants through root wounds [6-8], and tomato roots have an immune system that functions to protect the plant against $R$. solanacearum [26], and Si mainly accumulated in tomato roots $[9,23,27]$. For these reasons, the root is a suitable target for related mechanism analysis.

Salicylic acid (SA) plays a crucial role in the growth, development, and defense responses of plants [13,28,29]. SA can also inhibit microbial growth [29]. SA accumulation is a requirement for systemic acquired resistance (SAR) [30]. Exogenous SA application induces plant resistance to various pathogens through such mechanisms as oxidative burst, cell wall reinforcement and gene expression regulation [31]. Several studies show that SA application can enhance tomato resistance to $R$. solanacearum under greenhouse or field conditions [32,33]. Chen et al. [34] reported that ET-, SA- and MAPK-related defense signaling pathways were involved in the resistance of tomato to bacterial wilt. $R$. solanacearum degrades plant SA to protect itself from inhibitory levels of SA and also to enhance its virulence on hosts [30]. The salicylic acid-binding protein 2 (SABP2) is essential for the establishment of SAR [28], and our previous work reported that SABP2 transcripts were continuously down-regulated in Si-treated tomato plants [9].

Jacobs et al. [35] reported that $R$. solanacearum UW551 scrA mutant, with a defect of sucrose metabolism, was delayed in disease progress on susceptible tomato plants. The unexpected presence of sucrose in tomato xylem sap can provide $R$. solanacearum with a significant fitness advantage. They suggested that $R$. solanacearum depends on host sucrose for virulence on tomato [35]. Moreover, they found sucrose may also be an important nutrient for R. solanacearum only during the early stages of root infection in the host root [35]. Our recent soil culture experiment shows that sucrose contents in roots, xylem saps and leaves were almost maintained at a significantly higher level for Si-amended inoculated tomato plants compared with the controls [9]. Thus, in this study we measured sucrose 
concentrations in xylem fluid, root exudates and different organs from different treatments under hypertonic conditions, it would be useful to obtain a partial understanding of the role of sucrose in Si- and/or SA-induced tomato bacterial wilt resistance.

At present, hydroponic culture technology has been gradually applied to tomato production in the world [36]. The main reason for the rapid increase of hydroponic culture in recent years might partially be due to the easy control of soil-borne disease in those systems [36-38]. The contamination of pathogenic bacteria through the air, irrigation water and farming operation is recognized as a common set of risk factors for the hydroponic culture of tomato [39-41]. Commonly, temperature and relative humidity in the greenhouse stayed at a relatively stable high level, these conditions could actually be beneficial for the infection and spread of pathogenic bacteria [39]. In addition, it would not be easy to ensure that each plant roots received an equal quantity of inoculum in soil culture, but the roots of each tomato plant were exposed to the same concentration of pathogens in the hydroponic culture system [42]. Thus, the inoculation effect of $R$. solanacearum may be more stable in hydroponic tomato plants, relative to those in soil culture [42]. Meanwhile, some previous studies have reported that the hydroponic system is independent of the soil culture system, and the response of plants to various stresses differ between hydroponic and soil systems [43-46]. Therefore, the interaction between hydroponically grown tomato and $R$. solanacearum can potentially be used as a model to expand our understanding of the possible mechanisms of the effects of Si and SA against tomato bacterial wilt.

$\mathrm{Si}$ and SA application has been widely shown to increase the resistance of tomato to bacterial wilt $[3,4,32,33]$, but the effects of their combination on controlling tomato bacterial wilt have rarely been investigated. The objectives of this study were to explore the effects of the combined application of $\mathrm{Si}$ and SA on the defense responses of hydroponically grown tomato to $R$. solanacearum. We thus examined the effects of Si and SA application on the activities of the defense-related enzymes and the expression levels of defense-related genes in the roots of hydroponically grown tomato inoculated with $R$. solanacearum. In addition, root morphological traits, total soluble phenolics and lignin content in roots, endogenous hormones content (SA, JA, and ET) in roots, and sucrose concentrations in root exudates and different organs were also measured.

\section{Materials and Methods}

\subsection{Plant Materials and Treatments}

Bacterial wilt susceptible tomato (S. lycopersicum) line, HYT (provided by Dr. Guoping Wang, College of Horticulture, South China Agricultural University, Guangzhou, China) were used in this work. Tomato seeds were germinated and grown as described by Chen et al. [4] and Jiang et al. [9], with slight modifications. Briefly, seeds were surface-sterilized in water at $50{ }^{\circ} \mathrm{C}$ for $15 \mathrm{~min}$, germinated for two days in a petri dish with two layers of wet filter paper. Then, seeds were sown and grown in nursery plot containing a nursery soil composed of nutrition soil and organic fertilizer $(3: 1, v / v)$. Seeds were watered with sterile distilled water, and grown in a growth chamber at $30 / 25^{\circ} \mathrm{C}$ (day/night), $14 \mathrm{~h} \mathrm{light,}$ $200 \mu \mathrm{mol} \cdot \mathrm{m}^{-2} \cdot \mathrm{s}^{-1}$ light intensity, and $70 \%$ humidity. About 3 days after germination, seedlings were supplied with Hoagland's nutrient solution ( $\mathrm{pH}$ 6.5) twice a week. Healthy seedlings at the three-leaf stage were removed from the soil, and the growing soil medium was washed away from the roots with sterile water. The plants were then transplanted into hydroponics vessels ( $800 \mathrm{~mL}$ plastic bottles) containing $600 \mathrm{~mL}$ full-strength Hoagland nutrient solution ( $\mathrm{pH}$ 6.5). The plants were subjected to four different treatments (12 plants per treatment): (i) control treatment: tomato seedlings were watered regularly with nutrient solution without potassium silicate and SA, and each plant was inoculated with $R$. solanacearum, (ii) $+\mathrm{Si}$ treatment: seedlings were watered with nutrient solution containing $2.0 \mathrm{mM}$ potassium silicate $\left(\mathrm{K}_{2} \mathrm{SiO}_{3}\right)$ and individually inoculated with $R$. solanacearum, (iii) +SA treatment: seedlings were watered with nutrient solution containing $0.5 \mathrm{mM} \mathrm{SA}$ and individually inoculated with $R$. solanacearum, (iv) $\mathrm{Si}+\mathrm{SA}$ treatment: seedlings were watered with nutrient solution containing $2.0 \mathrm{mM} \mathrm{K}_{2} \mathrm{SiO}_{3}$ and $0.5 \mathrm{mM} \mathrm{SA}$, and each plant 
was inoculated with $R$. solanacearum. This $\mathrm{Si}$ concentration was chosen because our previous preliminary experiment found that $\mathrm{Si}$ application at $2.0 \mathrm{mM}$ significantly inhibited the typical development of bacterial wilt. For Si-negative treatments, potassium chloride $(\mathrm{KCl})$ was used to replenish potassium. Plants of the four treatments were irrigated daily with $30 \mathrm{~mL}$ of corresponding solution with the same $\mathrm{pH}$ value ( $\mathrm{pH}$ 6.5). Six replicates per treatment were performed. The plants were maintained in a growth chamber with the growth conditions as described above.

Inoculation of tomato plants with $R$. solanacearum was performed according to Chen et al. [4] and Jiang et al. [9], with slight modifications. In brief, a highly virulent necrotrophic $R$. solanacearum strain which belongs to race 1 biovar 3 was used for all inoculations. Bacteria were grown on TTC medium for 2 days at $30^{\circ} \mathrm{C}$. Bacteria were harvested from agar plates by rinsing with sterile distilled water and a $10^{8} \mathrm{CFU} \cdot \mathrm{mL}^{-1}$ suspension was used for inoculation. Tomato seedlings at the six-leaf stage were inoculated. For inoculations, $15 \mathrm{~mL}$ of the pathogen suspension was infused into each bottle. Whole plant samples were collected at 1, 2, 3 and 7 days post-infection (dpi), and at least three randomly selected plant individuals per time point and per type of treatment were used for further analysis.

\subsection{Bacteria Quantification, Symptom Evaluation, Measurement of Root Morphological Traits and Determination of Si Content}

Bacteria quantification was performed according to Dannon et al. [3]. Leaves, stems and roots of randomly selected tomato plants were sampled at 1,3, and $7 \mathrm{dpi}$ for quantification of $R$. solanacearum.

Disease severity was assessed daily after inoculation with $R$. solanacearum as described by Chen et al. [4]. Disease severity was assessed using an index of 0 to $9(0=$ no symptom, $9=$ stems collapsed or plants died). Disease index was calculated according to Jiang et al. [9].

The root morphological traits were measured as described by Fan et al. [27] with slight modifications. In brief, root samples collected at 7 dpi were used for morphological assays, roots were gently washed with distilled water to remove soil. The roots were then scanned with a digital scanner (STD1600, Epson, Long Beach, CA, USA). Images were acquired at a resolution of 800 dpi then analyzed with WinRHIZO Pro v.2012b software (Regent Instruments, Montreal, QC, Canada) for root length, diameter, volume, and surface area.

The concentration of $\mathrm{Si}$ in tomato leaves, stems and roots were determined at 1, 3 and $7 \mathrm{dpi}$ as described by Chen et al. [4] and Jiang et al. [9]. Briefly, the plant materials ( $0.1 \mathrm{~g})$ used to determine the concentrations of $\mathrm{Si}$ were dried for $72 \mathrm{~h}$ at $65^{\circ} \mathrm{C}$ and pulverized individually to powder with sufficient fineness to pass through a screen of 60-mesh screen. Then, sample was dissolved in 1.3\% hydrogen fluoride, and the Si content in the solutions was measured in a spectrophotometer (PGENERAL TU-1901 UV-VIS, Beijing, China) at $811 \mathrm{~nm}$. A standard curve was constructed using a series of silicon standard solutions, and used for determining the content of silica in the plant material. Finally, the Si content was calculated, adjusted and expressed in $\mathrm{mg} \cdot \mathrm{g}^{-1}$ dry weight.

\subsection{Enzyme Activity}

For peroxidase (POD), polyphenol oxidase (PPO) and phenylalanine ammonia lyase (PAL) activity assays, $0.1 \mathrm{~g}$ of the root tissue was ground with $1 \mathrm{~mL}$ of $50 \mathrm{mM}$ sodium phosphate buffer ( $\mathrm{pH}$ 7.0) and centrifuged at $12,000 \mathrm{~g}$ at $4{ }^{\circ} \mathrm{C}$ for $10 \mathrm{~min}$, and the supernatant was collected and used for enzyme assays. POD, PPO, PAL and LOX enzyme activities in roots were determined at various time points $(1,2,3$ and $7 \mathrm{dpi})$ using methods described previously [22,47]. The enzyme activities of chitinase (CHT) and $\beta-1,3$-glucanase (GLU) were determined following the method by El-Ghaouth et al. [48].

Sucrose synthase (SS), sucrose-phosphate synthase (SPS), acid invertases (AI) and neutral invertase (NI) activities in tomato leaves were also determined at various time points. Enzyme extracts of leaves were prepared by grinding $0.1 \mathrm{~g}$ leaf samples in liquid nitrogen and homogenized in corresponding extraction buffer. The homogenate was then 
centrifuged and the supernatant was used as enzyme extract. Extraction and subsequent enzyme activity assays were performed according to Balibrea et al. [49].

For each enzyme activity, at least three independent extractions and assays were performed for samples from each treatment and each time point.

\subsection{Determination of Total Soluble Phenolics, Lignin, Lignin-Like Phenolic Polymers and Sucrose}

At four sampling time points (1, 2, 3 and $7 \mathrm{dpi})$, the root samples of each plant per treatment were collected and $0.1 \mathrm{~g}$ of root samples were used to extract the total soluble phenolics (TSPs) and lignin and lignin-like phenolic polymers. The dried alcohol-insoluble residue from the TSP extraction was used for determination of lignin. Lignin was quantified by measuring the amount of lignin-thioglycolic acid (LTGA) derivatives. The concentration of TSP and LTGA were determined following the previously described methods [50].

Sucrose concentrations in root, leaf and xylem fluid of each treatment at $1 \mathrm{dpi}, 2 \mathrm{dpi}$, $3 \mathrm{dpi}$ and $7 \mathrm{dpi}$ were quantified by using a sucrose assay kit (Nanjing Jiancheng Bioengineering Institute, Nanjing City, China) following the manufacturer's recommendations. Xylem fluids were collected according to Jacobs et al. [35]. Tomato seedlings from each treatment and time point were used to determine sucrose concentration in root exudates, which were harvested and concentrated according to Fan et al. [27]. Each experiment was repeated three times with at least three biological replicates.

\subsection{Measurements of Hormone Contents}

ET, SA and JA contents in fresh root materials of each treatment at $1 \mathrm{dpi}, 2 \mathrm{dpi}, 3 \mathrm{dpi}$ and $7 \mathrm{dpi}$ were measured according to Jiang et al. [9] and Fan et al. [27]. For determination of ET, the roots $(0.5 \mathrm{~g})$ from each time point and treatment were respectively transferred to $2 \mathrm{~mL}$ glass vial, and all the bottles were sealed for $8 \mathrm{~h}$. Then, $1 \mathrm{~mL}$ of gas was taken by air-tight syringe to determine the ET. ET contents were measured using Agilent $6890 \mathrm{~N}$ gas chromatograph (GC) system with a flame ionization detector (FID) using a HP5 column $(30 \mathrm{~m} \times 0.25 \mathrm{~mm})$. The operating conditions of the GC were injection volume $=1 \mathrm{~mL}$, initial column temperature $=50^{\circ} \mathrm{C}$ for $3 \mathrm{~min}$, temperature increase rate $=15^{\circ} \mathrm{C} / \mathrm{min}$, final column temperature $=250{ }^{\circ} \mathrm{C}$ for $5 \mathrm{~min}$, carrier gas (nitrogen) flow rate $=40 \mathrm{~mL} / \mathrm{min}$, Hydrogen flow rate $=40 \mathrm{~mL} / \mathrm{min}$, air flow rate $=400 \mathrm{~mL} / \mathrm{min}$, temperature of injection port and detection port $=250{ }^{\circ} \mathrm{C}$. The SA and JA were determined using ultra-performance liquid chromatography-tandem mass spectrometry (UPLC-MS/MS). For extraction of SA and JA, freeze-dried roots were finely ground and $0.5 \mathrm{~g}$ was suspended in $1 \mathrm{ml}$ of extraction solvent (89.9\% MeOH:9.9\% $\mathrm{H}_{2} \mathrm{O}: 1 \%$ Acetic acid). These samples were sonicated $(50 \mathrm{~Hz})$ for $5 \mathrm{~min}$ and shook on a shaking platform for another $30 \mathrm{~min}$ at room temperature, and then the solution was stored at $4{ }^{\circ} \mathrm{C}$ for $24 \mathrm{~h}$. The mixture was centrifuged at $4{ }^{\circ} \mathrm{C}$ for $10 \mathrm{~min}$ at $13,000 \mathrm{rpm}$. The supernatants were kept and the plant debris was again re-suspended in $1 \mathrm{~mL}$ extraction solvent, shook and centrifuged. The supernatants were pooled and filtered using nylon syringe filters $(0.22 \mu \mathrm{m})$ and placed into a vial for UPLC-MS/MS analysis. A Waters ACQUITY UPLC system (Waters, Milford, MA, USA) was used with a Waters ACQUITY UPLC BEH $\mathrm{C}_{18}$ column $(2.1 \times 100 \mathrm{~mm}, 1.7 \mu \mathrm{m})$. The mobile phases consisting of mobile phase A (water with $1 \%$ formic acid) and mobile phase B (methanol with $1 \%$ formic acid) were used with a gradient elution of A/B $(v / v)$ from 60:40 (0-0.5 min, hold for $0.5 \mathrm{~min}$ ), 60:40 to $40: 60$ (0.5-4 $\mathrm{min}), 40: 60$ to 60:40 (4-4.5 $\mathrm{min}$ ), and 60:40 (4.5-6 $\mathrm{min}$, hold for $1.5 \mathrm{~min}$ ) at a flow rate of $0.40 \mathrm{~mL} \cdot \mathrm{min}^{-1}$. The injection volume for all samples was $10 \mu \mathrm{L}$. The column was maintained at $35^{\circ} \mathrm{C}$ during analysis. The UPLC system was coupled to Waters Quattro Premier XE in the multiple reaction monitoring (MRM) mode. The electrospray ionization (ESI) source was operated in positive and negative ionization switching modes in a single run. The first segment, with positive ESI mode, was designed between 0 and $4 \mathrm{~min}$. It allowed detection for SA. The second segment, with negative ESI mode, was used for detection of JA at the time period of 4.2-5.5 min. The operational parameters of ESI source were as follows: capillary potential $3000 \mathrm{~V}$; source temperature $150{ }^{\circ} \mathrm{C}$; desolvation temperature $450{ }^{\circ} \mathrm{C}$; cone gas flow $50 \mathrm{~L} \cdot \mathrm{h}^{-1}$; desolvation gas flow 
$600 \mathrm{~L} \cdot \mathrm{h}^{-1}$ and drying gas flow $15 \mathrm{~L} \cdot \mathrm{min}^{-1}$. The precursor ions, product ions, and MS/MS parameters are displayed in Table S1. All experiments were repeated at least three times with comparable results.

\section{6. qRT-PCR Analysis of Gene Expression of Defense-Related Genes}

The gene expression patterns of defense-related genes in the roots of single and combined treatments were determined by qRT-PCR. Total RNA was isolated from root tissues using the Trizol Kit (Promega, Madison, WI, USA) according to the manufacturer's instructions. Then the total RNA was treated with RNase-free DNase I (Takara Bio, Japan) at $37^{\circ} \mathrm{C}$ for $30 \mathrm{~min}$ to remove residual DNA. The RIN (RNA integrity number) values of the isolated RNA were determined using a Agilent 2100 Bioanalyzer (Santa Clara, CA, USA).

RNA samples with RIN of more than 7 were stored at $-80^{\circ} \mathrm{C}$, and used for qRT-PCR. The purified RNA (1ug) was reverse transcribed to cDNA using the FastQuant RT kit (with gDNase) (TIANGEN, Beijing, China). All qRT-PCR reactions were performed in a $20 \mu \mathrm{L}$ volume composed of $4 \mu \mathrm{L}$ of cDNA, $0.6 \mu \mathrm{L}$ of each primer $(10 \mu \mathrm{M} / \mu \mathrm{L}), 4.8 \mu \mathrm{L}$ of sterile water and $10 \mu \mathrm{L}$ qPCR master Mix using ABI Step One Plus Real-Time PCR System (Applied Biosystems, USA). The amplification cycling program was as follows: $90 \mathrm{~s}$ at $95^{\circ} \mathrm{C}$, followed by 40 cycles of $95^{\circ} \mathrm{C}$ for $5 \mathrm{~s}, 60^{\circ} \mathrm{C}$ for $15 \mathrm{~s}$, and $72{ }^{\circ} \mathrm{C}$ for $20 \mathrm{~s}$. All the primers for qRT-PCR are listed in Table S2. The phosphoglycerate kinase (PGK) was used as the internal control for normalization (Ghareeb et al., 2011). The relative changes in gene expression levels were calculated using the $2^{-\triangle \triangle C t}$ method [51]. qRT-PCR analysis was conducted with three technical replicates, and the data represent the means $\pm \operatorname{SE}(n=3)$.

\subsection{Statistical Analysis}

All data were expressed as the means \pm standard error (SE). A one-way ANOVA was performed to calculate the statistical significance of the observed differences using SPSS 19.0. the difference between the three expression values. Differences between means were evaluated for each experiment using Duncan's multiple range test at a significance level of $p<0.05$.

\section{Results}

3.1. Combined Application of Si and SA Can Enhance Disease Resistance to R. solanacearum in Hydroponically-Grown Tomato

Si- and/or SA-treated susceptible tomato plants were inoculated with $R$. solanacearum to assess the protective effect of combined application of $\mathrm{Si}$ and SA, and the disease development was evaluated daily for 7 days. Under hydroponic conditions, the wilt symptoms were first observed on leaves at $2 \mathrm{dpi}$ in the control plants, and the control plants were completely wilted (100\%) at $7 \mathrm{dpi}$ (Figure 1). In Si and/or SA treatments, the first wilt symptom was observed at $3 \mathrm{dpi}$ and they were only wilted to $32-37 \%$ at $7 \mathrm{dpi}$. Compared with the control plants, $\mathrm{Si}, \mathrm{SA}$, and combined $\mathrm{Si}+\mathrm{SA}$ treatments reduced the disease index by $60 \%, 66 \%$, and $70.08 \%$ at $7 \mathrm{dpi}$, respectively (Figure 1). Combined Si+SA treatment provided better disease control than Si or SA application alone (Figure 1). The bacterial number was measured in different tissues at 1,3 and $7 \mathrm{dpi}$, and no significant difference was observed for a bacterial number between Si-treated plants and controls (Figure 2a). The results showed that the single application of SA or combined application with $\mathrm{Si}$ could significantly reduce the bacterial number (Figure 2a). The number of bacteria in $\mathrm{Si}+\mathrm{SA}$ treatment was lower than that in the SA treatment, though there was no statistically significant difference between the two treatments (Figure 2a). The highest concentration of $\mathrm{Si}$ occurs in the root rather than other parts of plants (Figure $2 \mathrm{~b}$ ). Si alone or in combination with SA could significantly increase the Si content of tomato plants, but no significant difference was found between the two treatments (Figure $2 b$ ). For $+\mathrm{Si}$ treatment, root surface area, average diameter and root volume were increased by $44.4 \%, 17.5 \%$ and $25.0 \%$, respectively, at $7 \mathrm{dpi}$ when compared with that of control plants. (Table 1). In a single application of SA, root surface area, average diameter and root volume were increased 
by $41.26 \%, 12.63 \%$ and $27.70 \%$, respectively, at $7 \mathrm{dpi}$ when compared with those of the control plants (Table 1). In combined application of Si and SA, root length, root surface area, average diameter and root volume were increased by $47.68 \%, 125.40 \%, 22.09 \%$ and $37.70 \%$, respectively, at $7 \mathrm{dpi}$ when compared with those of the controls (Table 1). The combined application of Si and SA exhibited maximum value for root length, root surface area and average root diameter when compared with individual application of Si and SA (Table 1).

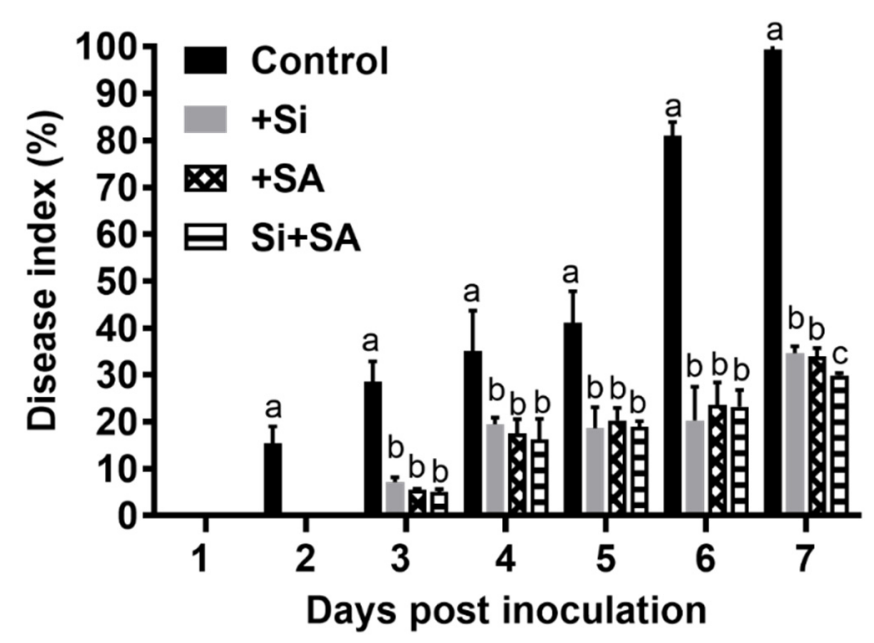

Figure 1. Effects of combined Si and salicylic acid (SA) treatment on the disease index of tomato bacterial wilt. Data presented as means \pm standard error (SE) of at least three independent experiments. Small letters indicate statistical differences among groups. Means followed by the same letters are not significantly different at $p<0.05$ based on Duncan's multiple range test.
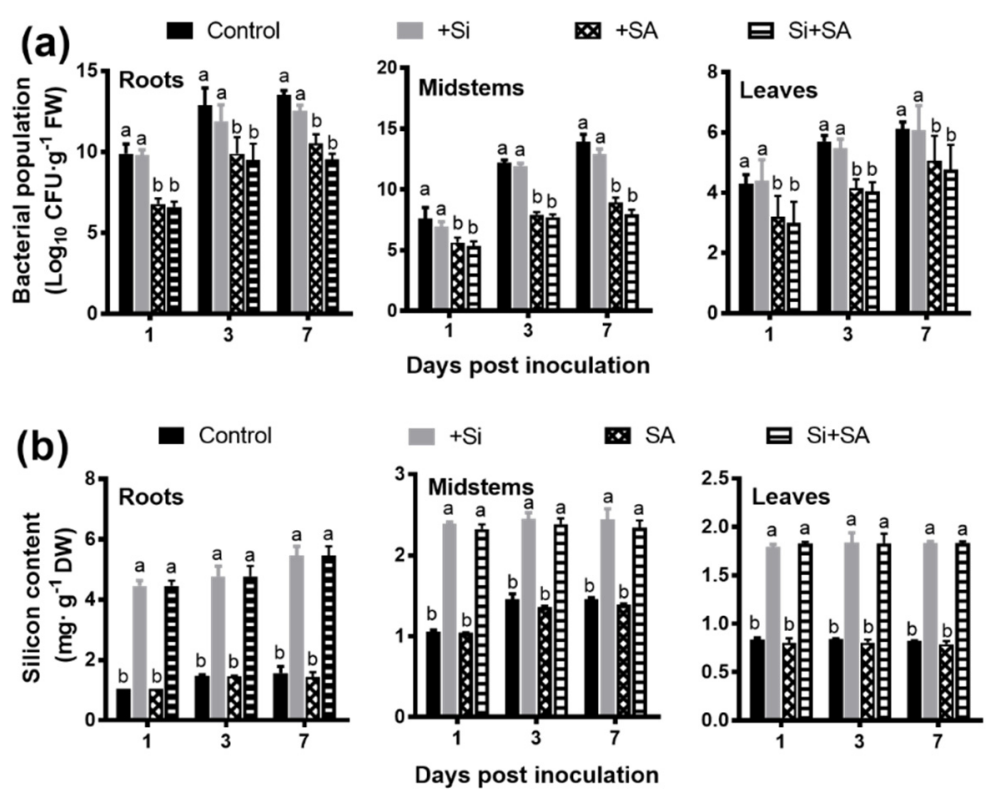

Figure 2. Effects of combined Si and SA treatment on bacterial numbers and silicon content in infected tomato plants. (a) Bacterial population. FW: fresh weight. (b) Silicon content. DW: dry weight. Data presented are means \pm standard error (SE) of at least three independent experiments. Different letters for each day indicate values that are significantly different $(p<0.05)$ according to Duncan's multiple range test. 
Table 1. Root morphological traits of different treatments.

\begin{tabular}{|c|c|c|c|c|}
\hline Treatment & $\begin{array}{l}\text { Root Length } \\
\text { (cm) }\end{array}$ & $\begin{array}{l}\text { Root Surface } \\
\text { Area }\left(\mathrm{cm}^{2}\right)\end{array}$ & $\begin{array}{l}\text { Average Root } \\
\text { Diameter (mm) }\end{array}$ & $\begin{array}{l}\text { Root Volume } \\
\qquad\left(\mathrm{cm}^{3}\right)\end{array}$ \\
\hline Control & $306.4 \pm 28.2^{b}$ & $25.2 \pm 3.6^{c}$ & $0.285 \pm 0.013^{c}$ & $0.252 \pm 0.023^{b}$ \\
\hline$+\mathrm{Si}$ & $321.5 \pm 44.85^{b}$ & $36.4 \pm 2.7^{b}$ & $0.335 \pm 0.018^{\mathrm{ab}}$ & $0.315 \pm 0.048^{\mathrm{a}}$ \\
\hline$+\mathrm{SA}$ & $311.6 \pm 27.2^{b}$ & $35.6 \pm 2.5^{b}$ & $0.321 \pm 0.004^{b}$ & $0.322 \pm 0.011^{\mathrm{a}}$ \\
\hline $\mathrm{Si}+\mathrm{SA}$ & $452.5 \pm 50.1^{\mathrm{a}}$ & $56.8 \pm 7.2^{\mathrm{a}}$ & $0.342 \pm 0.012^{\mathrm{a}}$ & $0.347 \pm 0.02^{\mathrm{a}}$ \\
\hline
\end{tabular}

Values are mean \pm SE $(n=6)$. Small letters indicate statistical differences among groups. Means followed by the same letters are not significantly different at $p<0.05$ based on Duncan's multiple range test.

\subsection{Effects of Combined Si and SA Treatment on Sucrose Metabolism in Hydroponically Grown Tomato Plants Inoculated with R. solanacearum}

Compared with the control plants, $\mathrm{Si}, \mathrm{SA}$, and $\mathrm{Si}+\mathrm{SA}$ treatments significantly increased root sucrose content by $13.23 \%, 13.78 \%$ and $13.91 \%$ at $7 \mathrm{dpi}$, respectively, but no significant difference was found among the three groups (Figure 3a). Leaf sucrose content slightly decreased from 1 dpi to $7 \mathrm{dpi}$, and xylem sap sucrose concentration increased from $1 \mathrm{dpi}$ to $3 \mathrm{dpi}$. The leaf and xylem sap sucrose concentrations in both the single and combined treatments were significantly higher than those of the controls at $1 \mathrm{dpi}, 2 \mathrm{dpi}, 3 \mathrm{dpi}$ and $7 \mathrm{dpi}$, but no significant difference was found among the three treated groups (Figure $3 b, c$ ). Under the single and combined treatments of Si and SA, the concentration of sucrose in root exudates increased gradually from $1 \mathrm{dpi}$, reached the peak at $7 \mathrm{dpi}$, and the contents in $\mathrm{Si}, \mathrm{SA}$, and $\mathrm{Si}+\mathrm{SA}$ treatments were significantly higher at $2 \mathrm{dpi}, 3 \mathrm{dpi}$ and $7 \mathrm{dpi}$ than those of the controls, but no significant statistical differences were observed among the three treated groups (Figure 3d).

Subsequently, sucrose synthase (SS), sucrose synthesis (SPS), acid invertase (AI) and neutral invertase (NI), which were the enzymes involved in the sucrose metabolism, were measured in leaf samples. SPS activity decreased gradually from $1 \mathrm{dpi}$ to $7 \mathrm{dpi}$, its activities were significantly higher in $\mathrm{Si}, \mathrm{SA}$, and $\mathrm{Si}+\mathrm{SA}$ treatments during the entire experimental period in comparison with the controls, though no significant differences were observed among the three treated groups (Figure 3e). The activities of SS (synthesis), NI and AI were increased gradually from $1 \mathrm{dpi}$ to $3 \mathrm{dpi}$, and subsequently decreased at $7 \mathrm{dpi}$, and their activities were significantly higher in $\mathrm{Si}, \mathrm{SA}$, and $\mathrm{Si}+\mathrm{SA}$ treatments than those of the controls at $3 \mathrm{dpi}$ (Figure $3 \mathrm{f}-\mathrm{h}$ ). The activities of NI and AI significantly increased by $6.00 \%$ and $4.54 \%$ at $3 \mathrm{dpi}$, respectively in the $\mathrm{Si}+\mathrm{SA}$ treatment compared with the Si supplied alone (Figure 3g,h). 


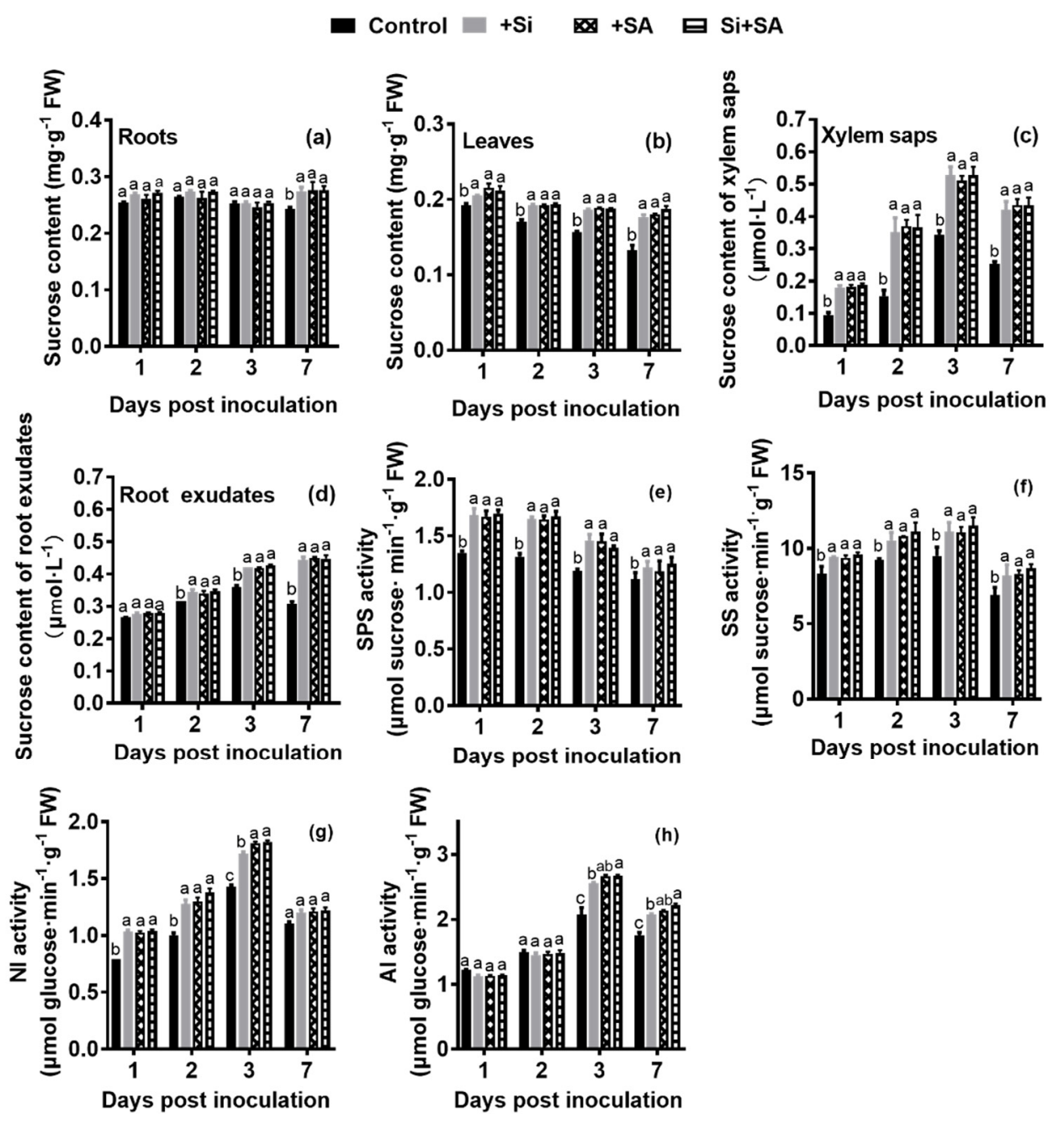

Figure 3. Effects of combined Si and SA treatment on sucrose concentration and activities of enzymes related to sucrose metabolism in treated plants at different time points after infection. Sucrose contents in roots (a), leaves (b), xylem saps (c) and root exudates (d) of treated plants. The SPS (e), SS (f), NI (g) and AI (h) activities in leaf extracts in the same samples. AI, acid invertase; NI, neutral invertase; SS, sucrose synthase; SPS, sucrose-phosphate synthase. Small letters indicate statistical differences among groups. Means followed by the same letters are not significantly different at $p<0.05$ based on Duncan's multiple range test. $\mathrm{FW}=$ fresh weight.

\subsection{Effects of Combined Si and SA Treatment on Biochemical Parameters in Hydroponically Grown Tomato Roots Inoculated with R. solanacearum}

We performed biochemical analyses to further evaluate the effects of combined application of $\mathrm{Si}$ and $\mathrm{SA}$ on tomato resistance against $R$. solanacearum infection, the activities of defense-related enzymes (PAL, PPO, POD, LOX, CHT and GLU) and the concentrations of TSPs and LTGA derivatives were measured at various time points after inoculation. Under the single and combined treatments of Si and SA, the activities of PAL and PPO, and the content of TSPs and LTGA derivatives significantly increased from 1 to $3 \mathrm{dpi}$, peaked at $3 \mathrm{dpi}$ and decreased thereafter (Figure $4 \mathrm{a}, \mathrm{b}, \mathrm{g}, \mathrm{h}$ ). The activities of PAL, PPO, POD, CHT and GLU, and the content of TSPs and LTGA derivatives were consistently higher in Si, SA, and $\mathrm{Si}+\mathrm{SA}$ treatments at 2 and 3 dpi in comparison to the controls (Figure $4 \mathrm{a}-\mathrm{c}, \mathrm{e}-\mathrm{h}$ ). PPO activity with $\mathrm{Si}+\mathrm{SA}$ treatment was significantly higher than that of $\mathrm{Si}$ or $\mathrm{SA}$ single treatment at 2 dpi (Figure $4 b$ ). The activity of POD was significantly higher (1.27- to 1.34-fold) in the $\mathrm{Si}+\mathrm{SA}$ treatments at $7 \mathrm{dpi}$, relative to those in the two single treatments (Figure $4 \mathrm{c}$ ). The activities of $\mathrm{LOX}$ in $\mathrm{Si}, \mathrm{SA}$, and $\mathrm{Si}+\mathrm{SA}$ treatments increased gradually from $1 \mathrm{dpi}$, reached 
the peak at $2 \mathrm{dpi}$, and a sharp decrease was observed at $3 \mathrm{dpi}$ and $7 \mathrm{dpi}$ (Figure $4 \mathrm{~d}$ ). For the control plants, the activity of LOX was increased linearly with time, and LOX activity increased 1.45 to 2.00 times during $3 \mathrm{dpi}$ to $7 \mathrm{dpi}$ compared with Si and/or SA treatments (Figure $4 \mathrm{~d}$ ). The activity of GLU was increased linearly with time. Compared with the control group, $\mathrm{Si}, \mathrm{SA}$, and $\mathrm{Si}+\mathrm{SA}$ treatments significantly increased the GLU activity by $42.38 \%, 40.43 \%$ and $43.69 \%$ at $7 \mathrm{dpi}$, respectively, no significant differences were observed among the three treated groups (Figure $4 \mathrm{f}$ ).

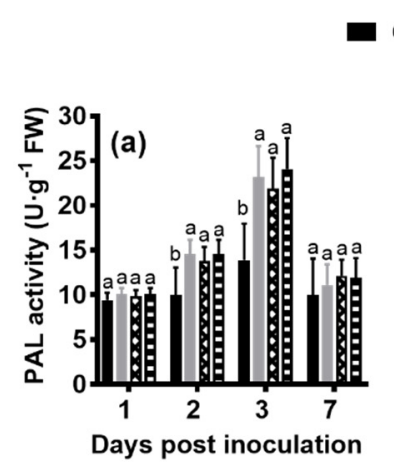

Control +Si $\quad$ Q + SA $\quad$ Si+SA
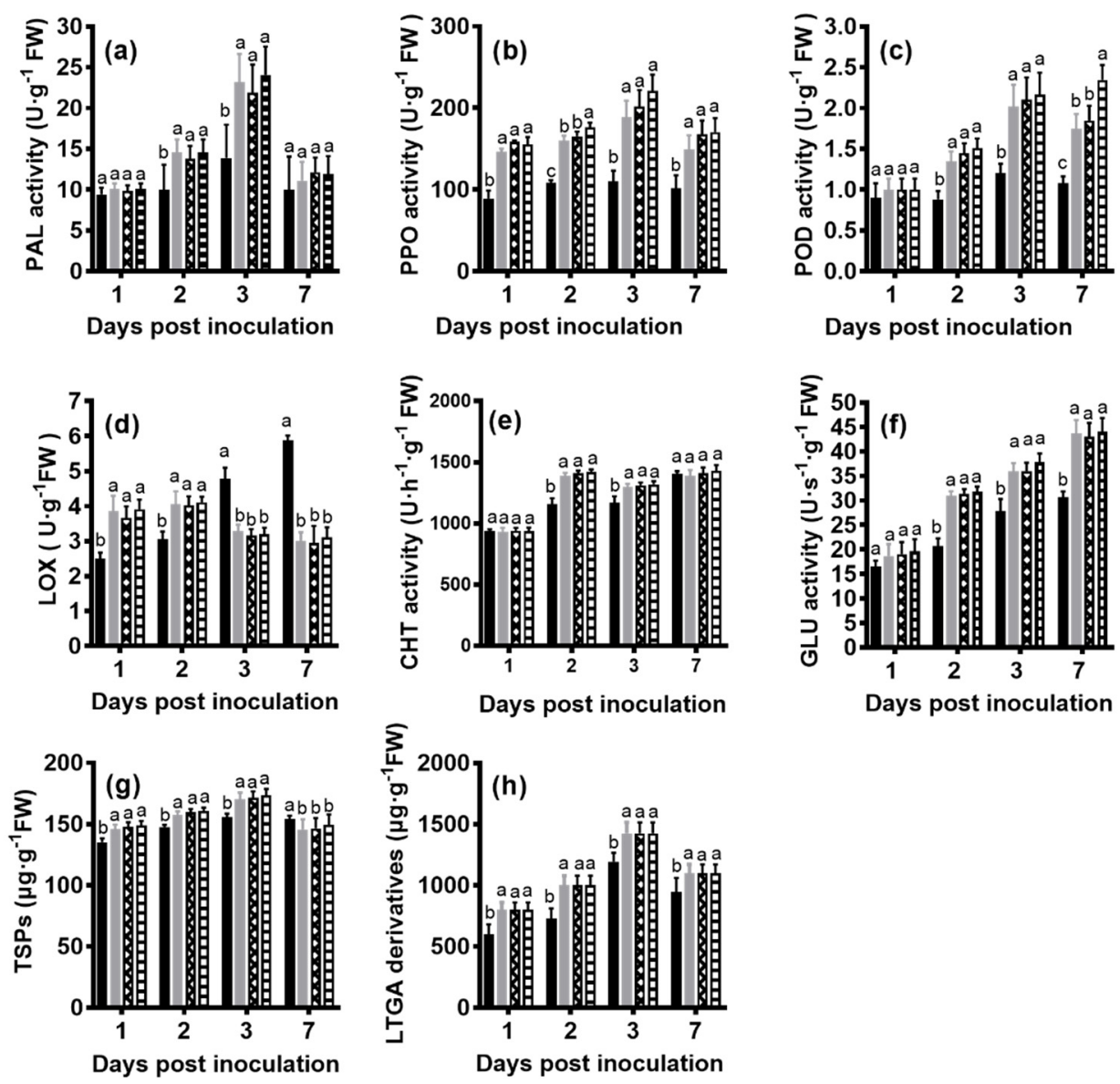

Figure 4. Effects of combined Si and SA treatment on biochemical parameters. Activities of phenylalanine ammonia-lyases (PAL) (a) peroxidase (POD) (b), polyphenoloxidases (PPO) (c), lipoxygenases (LOX) (d), chitinase (CHT) (e) and $\beta-1,3-$ glucanase (GLU) (f) in root tissue of treated plants at different times after inoculation with $R$. solanacearum. Concentrations of total soluble phenols (TSPs) (g) and lignin-thioglycolic acid (LTGA) derivatives (h) in treated tomato roots after infection. Data are means \pm standard error (SE) of at least three independent trials. Means followed by the same letters are not significantly different at $p<0.05$ based on Duncan's multiple range test. FW $=$ fresh weight.

\subsection{Effects of Combined Si and SA Treatment on the Changes of ET, JA and SA Contents in Hydroponically Grown Tomato Roots Inoculated with R. solanacearum}

ET production increased over time in both treatments, and ET release rate of the control plants was significantly higher compared with the remaining treatments throughout the test period. In the early stage of the infection $(1 \mathrm{dpi})$, the control plants emitted significantly more ET (1.37- to 2.22-fold), relative to the remaining treatments. At $7 \mathrm{dpi}$, there was significantly more ET production (1.45- to 3.44-fold) in the control plants compared with those of the remaining treatments (Figure 5a). At $7 \mathrm{dpi}$, ET release rate of the Si treatment was 1.58 to 1.71 times higher than that of the Si+SA treatment (Figure 5a). 


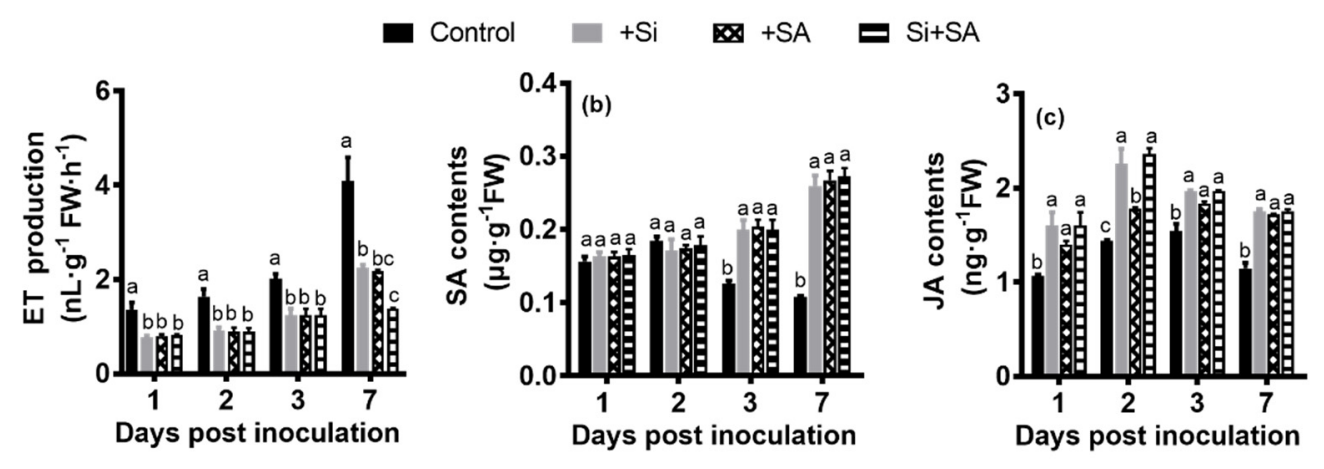

Figure 5. Hormone measurements of treated plants at different time points after infection. (a) ET production; (b) SA content; (c) JA content. FW: fresh weight. Data presented are means \pm standard error (SE) of at least three independent experiments. Means followed by the same letters are not significantly different at $p<0.05$ based on the Duncan's multiple range test. $\mathrm{FW}=$ fresh weight.

SA contents increased with time in $\mathrm{Si}, \mathrm{SA}$, and $\mathrm{Si}+\mathrm{SA}$ treatments, and SA contents were significantly higher for the single and combined treatments at $3 \mathrm{dpi}$ and $7 \mathrm{dpi}$ in comparison to control plants (Figure $5 b$ ). In the control plants, the contents of SA sharply increased from $1 \mathrm{dpi}$ to $2 \mathrm{dpi}$, peaked at $2 \mathrm{dpi}$ and decreased thereafter (Figure $5 \mathrm{~b}$ ). Under the single and combined treatments of $\mathrm{Si}$ and $\mathrm{SA}$, the contents of SA were 2.15 to 2.67 times higher than those of the controls at $7 \mathrm{dpi}$ (Figure $5 \mathrm{~b}$ ). No significant changes in SA content were observed between individual and combined treatments (Figure $5 b$ ).

JA contents slightly increased from $1 \mathrm{dpi}$ to $2 \mathrm{dpi}$, peaked at $2 \mathrm{dpi}$, and then decreased thereafter (Figure 5c). In comparison with the control plants, JA contents were significantly higher for the single and combined treatments during the entire experimental period (Figure 5c). At $2 \mathrm{dpi}, \mathrm{Si}$ alone or in combination with SA could significantly increase the contents of endogenous JA when compared with SA applied alone (Figure 5c). No significant changes in the content of JA were observed between individual and combined treatments at $1 \mathrm{dpi}, 3 \mathrm{dpi}$ and $7 \mathrm{dpi}$ (Figure 5c).

3.5. Effects of Combined Si and SA Treatment on the Expression Levels of Defense-Related Genes in Hydroponically Grown Tomato Roots Inoculated with R. solanacearum

Different genes may have different responses to exogenous SA and Si. The PAL transcripts were significantly induced in $\mathrm{Si}, \mathrm{SA}$, and $\mathrm{Si}+\mathrm{SA}$ treatments at 3 dpi relative to the control plants, and its expression was decreased dramatically at 7 dpi. For the control plants, the $P A L$ expression was decreased dramatically at $3 \mathrm{dpi}$, and significant induction of $P A L$ gene was observed at $7 \mathrm{dpi}$ (Figure 6a). In the Si-SA combination treatments, the expression of $P A L$ was significantly higher (1.22-fold) in comparison to that of the SA treatment (Figure 6a).

Compared with control plants, $\mathrm{Si}$ and/or SA treatments significantly induced transcripts of $P O D$ at $1 \mathrm{dpi}$ and $3 \mathrm{dpi}$, however, no difference was observed between individual and combined treatments at $1 \mathrm{dpi}$ and $3 \mathrm{dpi}$ (Figure 6b). For the control plants, the expression of $P O D$ was continuously up-regulated, and its expression was significantly higher at $7 \mathrm{dpi}$ in comparison with that of other treatments (Figure 6b). At $7 \mathrm{dpi}$, the expression level of $P O D$ was significantly higher (1.03- to 1.12-fold) for the Si+SA treatment when compared with that of Si and SA supplied alone (Figure 6b). 

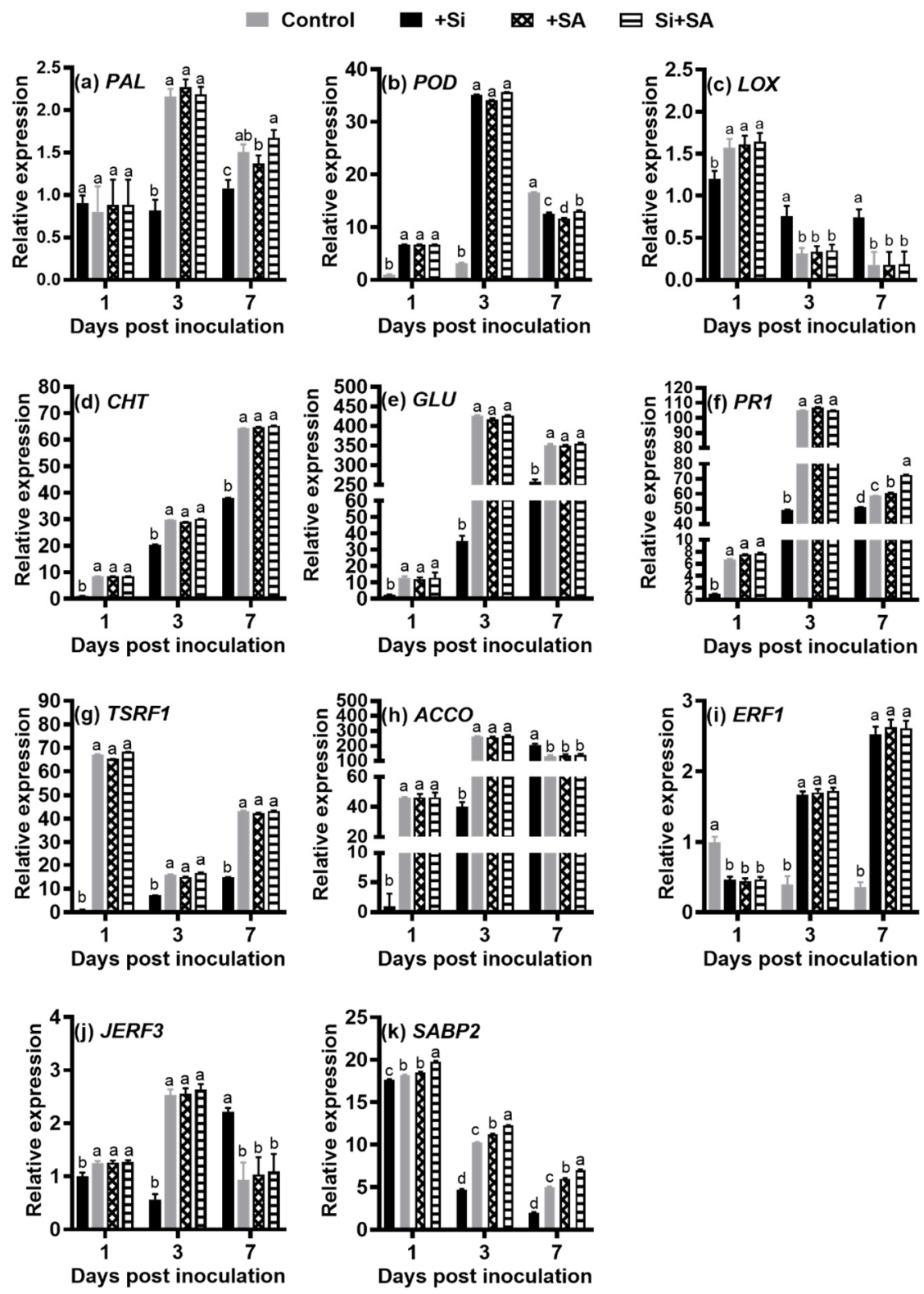

Figure 6. Expression of the selected 11 genes revealed by qRT-PCR. The qRT-PCR data showed the mean values from at least three replicates and the error bars represent the standard error (SE) of the means. (a) Relative expression levels of PAL transcripts; (b) Relative expression levels of POD transcripts; (c) Relative expression levels of LOX transcripts. (d) Relative expression levels of CHT transcripts; (e) Relative expression levels of GLU transcripts; (f) Relative expression levels of PR1 transcripts; (g) Relative expression levels of TSRF1 transcripts; (h) Relative expression levels of ACCO transcripts; (i) Relative expression levels of ERF1 transcripts; (j) Relative expression levels of JERF3 transcripts; (k) Relative expression levels of $S A B P 2$ transcripts. Means followed by the same letters are not significantly different at $p<0.05$ based on Duncan's multiple range test. FW $=$ fresh weight. PAL: phenylalanine ammonia-lyase; POD: peroxidase; LOX: lipoxygenase; CHT: chitinase; GLU: beta-1,3-glucanase; PR1: pathogenesis-related protein 1; TSRF1: tomato stress-responsive factor 1; ACCO: 1-Aminocyclopropane-1-carboxylic acid oxidase; ERF1: ethylene response factor 1; JERF3: Jasmonate and ethylene responsive factor 1; SABP2: salicylic acid-binding protein 2.

The highest level of LOX expression was observed at $1 \mathrm{dpi}$ in the Si+SA treatment, and a sharp decrease was observed at $3 \mathrm{dpi}$ and $7 \mathrm{dpi}$, but no significant changes in gene expression of $L O X$ were noted between individual and combined treatments. For the control plants, the expression of $L O X$ was induced by 2.14 - to 2.40 -fold at $1 \mathrm{dpi}$ and was 
increased by $4.02-$ to 4.11 -fold at $7 \mathrm{dpi}$ when compared with the levels of corresponding time points in other treatments (Figure 6c).

The CHT transcripts in both treatments were continuously up-regulated. The expression of $C H T$ was significantly higher for single and combination treatments at 1,3 and $7 \mathrm{dpi}$ in comparison with that of the control plants, but no significant changes in gene expression of $\mathrm{CHT}$ were observed between individual and combined treatments (Figure 6d).

For GLU, its expression level was significantly higher in both individual and combined treatments than that in the control plants. The GLU transcripts in the control plants were continuously up-regulated (Figure 6e). For single and combination treatments, GLU was induced at $1 \mathrm{dpi}$, and its peak expression was observed at $3 \mathrm{dpi}$, but decreased thereafter. No significant changes in gene expression of GLU were observed between individual and combined treatments (Figure 6e).

The expression patterns of PR1 gene were similar to those of GLU gene, but PR1 expression level was more than 1.20 times higher in the $\mathrm{Si}+\mathrm{SA}$ treatment than those in the remaining treatments at $7 \mathrm{dpi}$ (Figure $6 \mathrm{f}$ ).

The TSRF1 transcripts in single and combined treatments were down-regulated from 1 dpi to 3 dpi and dramatically up-regulated from 3 dpi onwards. For single and combination treatments, the highest level of TSRF1 expression was observed at $1 \mathrm{dpi}$ (Figure 6g). For the control plants, the TSRF1 transcripts were continuously up-regulated, but its expression level was significantly lower than that in other treatments (Figure 6g).

For $A C C O$, its expression level was significantly higher in both individual and combined treatments than those in the control plants at $1 \mathrm{dpi}$ and $3 \mathrm{dpi}$. For single and combination treatments, $A C C O$ was induced at $1 \mathrm{dpi}$, and its expression peaked at $3 \mathrm{dpi}$, but decreased thereafter. The ACCO transcripts in the control plants were continuously up-regulated, its expression level was significantly higher (more than 1.48 times higher) when compared with those of single and combined application of Si and SA at $7 \mathrm{dpi}$ (Figure $6 \mathrm{~h}$ ).

The ERF1 transcripts in the control plants were continuously down-regulated, but the initial level of ERF1 expression was more than 2.16 times higher in the control plants than those in the remaining treatments. Compared with the control plants, both single and combined treatments significantly increased the ERF1 expression by more than 4.24-fold at $3 \mathrm{dpi}$, and by more than 7.09 -fold at $7 \mathrm{dpi}$, respectively, but no significant changes in gene expression of ERF1 were observed between individual and combined treatments (Figure 6i).

Compared with the control group, $\mathrm{Si}$ and/or SA treatments significantly induced the transcripts of JERF 3 at $1 \mathrm{dpi}$ and $3 \mathrm{dpi}$, however, no difference was observed between individual and combined treatments at $1 \mathrm{dpi}$ and $3 \mathrm{dpi}$ (Figure 6j). For the control plants, the expression level of JERF 3 was down-regulated from $1 \mathrm{dpi}$ to $3 \mathrm{dpi}$ and dramatically up-regulated from $3 \mathrm{dpi}$ afterwards, and its expression was significantly higher (more than 2.02 times higher) at $7 \mathrm{dpi}$ in comparison with those of other treatments (Figure 6j).

The $S A B P 2$ transcripts in both treatments were continuously down-regulated, but the expression level of $S A B P 2$ was significantly higher for single and combination treatments when compared with those of the control plants (Figure 6k). Moreover, the expression level of $S A B P 2$ was significantly higher for combination treatment when compared with those of plants with $\mathrm{Si}$ and SA supplied alone (Figure 6k).

\section{Discussion}

Ralstonia solanacearum, a soilborne pathogenic bacterium that typically invades plants through the root wounds and colonizes host plant xylem vessels [35]. In vascular plants, $R$. solanacearum infection is strongly associated with reduced water transport leading to whole-plant water stress, which ultimately leads to plant wilting and rapid death $[52,53]$. Silicon has been extensively shown to increase plant disease resistance and stress tolerance [12,25]. Several studies have reported that SA application can enhance tomato resistance to $R$. solanacearum under greenhouse and/or field conditions [32,33]. The goal 
of this research was to assay the combined effect of $\mathrm{Si}$ and SA on controlling tomato bacterial wilt.

Single and combined application of Si and SA resulted in a substantial reduction in wilt disease severity under our conditions (Figure 1), consistent with several previous studies $[3,4,8,9,32,33]$. However, combined application of Si and SA showed a stronger suppressing effect on wilt disease severity than individual treatments (Figure 1), we suggested that combined Si and SA treatment in the present study had synergistic effects on the control of tomato bacterial wilt. Numerous studies have reported that the accumulation of $\mathrm{Si}$ in plant organs acts as a mechanical barrier that prevents penetration by pathogens [12,25]. In the terms of the number of bacterial colonies, no significant difference was observed in tomato plants between the control group and the experimental group with Si treatment (Figure 2a), but Si application still reduced bacterial wilt development (Figure 1).SA is an antimicrobial compound, and SA toxicity influences the composition of the microbial community [29]. SA alone or in combination with Si could significantly decrease the number of bacterial colonies (Figure 2a), but no significant difference was found between treatments, which indicated that combination of Si and SA treatment in the present study had no synergistic effects to suppress $R$. solanacearum population density (Figure 2a). In the present study, Si accumulated mainly in the tomato roots (Figure 2b), which is typically characteristic of Si non-accumulator tomato plants [54]. Compared with the Si supplied alone, the content of Si was not affected by combined exposures to $\mathrm{Si}$ and SA (Figure 2b), and it was speculated that SA did not affect the deposition of Si in tomato plants. Previous studies indicate that morphological changes that lead to the increase of root surface area and lateral root formation, could be functionally associated with stress avoidance mechanisms [55-58]. Another study has shown that $S i$ treatment results in enhanced root growth, and increased root surface area in R. solanacearum-infected tomato plants [27]. Notably, it was found that the root morphology such as root surface area, average diameter and root volume was significantly increased in single and combined treatments, and combined application of Si and SA showed a stronger enhancing effect on all root morphological traits than individual treatments under the experimental conditions (Table 1). The increase of these traits might be able to improve the uptake of water and nutrients of plants [59]. Thus, it is suggested that the combined application of Si and SA significantly increased bacterial wilt tolerance of hydroponically grown tomato by improving root morphological characteristics, which in turn can lead to improving the uptake of water and nutrients, and thereby partly alleviating the water-deficit stress caused by $R$. solanacearum infection.

Si alone or in combination with SA did not reduce the root sucrose content of $R$. solanacearum-infected tomato, and no significant difference was found between treatments (Figure 4a-d), which were partly consistent with our previous study [9]. Sucrose content was almost maintained at a significantly higher level for single and combination treatments in comparison to the control group (Figure 3a-d). Pathogen invades the host plant to acquire nutrients which are majorly sugars, to support their multiplication [60]. We all know that stress response is an energy-consuming process, sucrose is an important source of energy for plant growth and development [61]. Sucrose synthesis is catalyzed by SPS and SS (synthesis), and NI and AI are the major enzymes responsible for sucrose decomposition [62]. With the increase in activities of NI and AI, sucrose was decomposed into soluble sugars, which are a key part of osmolytes facilitating plant stress adaptation [63]. It has also been reported that leaf sucrose contents decline during water deficit stress to overcome stress [64]. Under $\mathrm{NaCl}$ stress, SA could enhance the activities of AI and NI in tomato leaves, and then contribute to enhance the salt tolerance of tomato plants [65]. In the current study, the decrease of leaf sucrose contents could be associated with a significant increase in the activities of NI and AI and a decrease in activities of SPS and SS (synthesis) (Figure 4g,h). Compared with the Si treatment, the combined application of $\mathrm{Si}$ and SA significantly enhanced NI and AI activities in the leaves of infected tomato plants at $3 \mathrm{dpi}$ (Figure $4 \mathrm{~g}, \mathrm{~h}$ ), and we suggested that combined Si and SA treatment in the present 
study had synergistic effects on the activities of NI and AI. A similar dynamic change trend of these sucrose-metabolizing-related enzyme activities was observed in tomato plants under water stress and salt stress, and the author considers that sucrose and these sucrose-metabolizing related enzymes might have contributed to alleviating water stress and osmotic stress [66]. The growth capacity of tomato plants under water deficit stress and salt stress is related to the increase in sink activity [66]. The promotion of sucrose output to the sink tissues results in the accumulation of sucrose in roots (sink), which leads to better adaptability to water deficit stress [64]. A similar trend with the accumulation of osmolytes such as sucrose, under water-deficit and salinity stress, was recorded [66,67]. Hence, our preliminary data suggest that, in single and combination treatments, the higher sucrose contents, together with sucrose-metabolizing related enzymes activities, may be involved in alleviating the water-deficit stress caused by $R$. solanacearum infection, and as well as maintaining the supply of adaptive energy to deal with stress, thereby indirectly and partially increasing the tolerance of tomato to bacterial wilt.

Root exudates play an important role in microbial colonization of the rhizosphere [68]. Sucrose is an easily available carbon source for soil microbes [69]. Our group and others have reported that Si-mediated tomato resistance against $R$. solanacearum is associated with the modification of the rhizosphere microbial community structure $[23,24,70]$. In the study by $\mathrm{Gu}$ et al. [71] found that five sugars (sucrose, melibiose, etc.) decreased the soil bacterial abundances, and the soils were conditioned with 12 carbon sources (sucrose, maltose, etc.) significantly decreased the bacterial wilt disease incidence. As mentioned above, Jacobs et al. [35] suggested that sucrose may be an important nutrient for $R$. solanacearum during the early stages of root infection in the host root. It has been reported that Pseudomonas syringae pv. syringae can significantly alter the transport of sources in Phaseolus vulgaris [72]. In the present study, it was found that the concentration of sucrose in root exudates was significantly increased in single and combination treatments, but the results suggested that the combination of Si and SA treatment in the present study had no synergistic effects on the sucrose content of root exudates (Figure 4d). Hence, we speculated that increasing the sucrose content of root exudates in single and combined treated plants under hydroponic culture conditions might partly contribute to enhancing resistance to $R$. solanacearum. Meanwhile, plant pathogens can manipulate the host to enhance its adaptability [35,73], thus it cannot be ruled out that this result is due to pathogen-mediated manipulation of host metabolism in the hydroponic system. Furthermore, sucrose is a signaling molecule [74]. The study of Gómez-Ariza et al. [75] found that pretreatment of rice plants with sucrose enhances resistance to blast disease, and the expression of the rice defense genes was induced by exogenous sucrose. Therefore, in single and combined treatments, the role of sucrose can be far more complicated than it may seem.

Defense-related enzymes are closely associated with bacterial wilt disease resistance $[9,25]$. Numerous studies showed that PAL, PPO, POD and LOX are key enzymes conferring disease resistance in plants. PAL takes part in the biosynthesis of SA, phenolic compounds, phytoalexin and lignin [76]. POD plays an important role in regulating the production and accumulation of antimicrobial compounds (lignin, phenolics, etc.) [77]. PPO is able to oxidize phenolic compounds to antimicrobial quinines, thus contribute to plant defense against pathogens [22,50]. Antimicrobial compounds can inhibit the growth of pathogenic bacteria [25]. It has also been reported that lower total lignin content aggravated the severity of tobacco bacterial wilt diseases, while increased lignin alleviated the disease symptoms [78]. Defense-induced lignification is a basal defense mechanism in the plant immune response against biotrophic and hemibiotrophic plant pathogens in various plant species [72]. Major mechanisms underlying lignification-based resistance are proposed as establishing mechanical barriers to pathogen invasion and limiting the diffusion of toxins from the pathogen to the host plants [79]. SA could elevate the activities of defense-related enzymes in many plant-pathogen interactions [80,81]. SA also affected the accumulation of phenolic compounds which are associated with plant resistance [81]. SA could induce strong and rapid lignin deposition in the tomato root cell wall, which could be specifically 
targeted against $R$. solanacearum [82]. In the present study, it was found that single and combined treatments have led to an increase in the activities of PAL, PPO and POD and increment of phenolic compounds and lignin (LTGA derivatives) content (Figure $4 a-c, g, h$ ). Hence, the basal resistance response includes the accumulation of antimicrobial compounds and the reinforcement of root cell walls by the LTGA derivatives might partly contribute to the synergistic effects of $\mathrm{Si}$ and SA on the control of tomato bacterial wilt. Considerably, the activity of POD was significantly higher (1.27- to 1.34-fold) in the Si+SA treatment at 7 dpi (Figure 4c), and PPO activity with Si+SA treatment was significantly higher than $\mathrm{Si}$ or SA single treatment at 2 dpi (Figure $4 \mathrm{~b}$ ), which indicated that PPO and POD may play a more significant role in the synergistic effects of $\mathrm{Si}$ and SA. In addition, changes in the activities of these defense-related enzymes (Figure 4), coupled with no statistically significant differences were detected in the numbers of bacterial colonies between SA and Si+SA treatments (Figure 2a), we speculated that the change of related enzyme activities may be partly associated with the alteration of the pathogenicity and fitness of $R$. solanacearum, thereby making a partial contribution to delay the development of wilt symptoms. PAL, PPO and POD also act as antioxidant enzymes, and the activities of antioxidant enzymes help the plants to reduce the excess reactive oxygen species (ROS) which is the source of oxidative stress during pathogen infection [83]. Previous work has shown that under stress, SA can maintain the activity of antioxidant enzymes to some extent, and it might also help to limit the impact of the oxidative processes associated with the development and spread of the lesion, and hence, SA may have an important antioxidant role in oxidative processes associated with plant defense responses [84,85]. Unexpectedly, as compared with the control plants, the content of SA was relatively high from $1 \mathrm{dpi}$ to $7 \mathrm{dpi}$ in the single and combination treatments (Figure $5 b$ ). Based on the above results, it was suggested that mitigation of oxidative stress by activated antioxidant enzymatic systems might partly contribute to the synergistic effects of Si and SA on the control of tomato bacterial wilt. Generally, CHT can hydrolyze chitin and thus contribute to plant defense against certain fungal pathogens [86]. CHT can also confer resistance to other biotic and abiotic stresses, such as bacterial pathogens, salinity, etc [87]. GLU plays a role in plant resistance against fungal or bacterial infections [88], and it may prevent bacterial spread in tomato- $R$. solanacearum interaction systems [89]. The overexpression of the GLU gene can enhance tomato resistance to R. solanacearum [90]. Correspondingly, in this study, CHT and GLU enzyme activities (Figure 4e,f) and mRNA expression (Figure 6d,e) were significantly increased in single and combination treatments and these changes may contribute to improving plant resistance and tolerance to $R$. solanacearum infection.

The plant stress hormones ET, JA and SA play a dominant role in regulating the plant defenses against pathogens [91]. ET and JA are known to be involved in defense against necrotrophic pathogens [92]. The final step in the biosynthesis of ET is catalyzed by 1-aminocyclopropane-1-carboxylic acid oxidase (ACCO). ET treatment results in enhanced disease development with necrotrophic pathogens [93,94]. Hemibiotrophic pathogens display a biotrophic phase during early infection [95], and the fact that $R$. solanacearum has a hemibiotrophic phase during the early stages of infection [96]. The hemibiotrophic pathogens may be able to manipulate the host plant to produce ET for facilitating a fast transition from the hemibiotrophic phase to the necrotrophic phase [97]. In addition, many studies have shown that pre-treatment with SA led to decreased ethylene production in many plants $[98,99]$. In our previous study, it was reported that under soil culture conditions, the release of ET was delayed in Si treatments [9]. In the present study, ET production was significantly increased from 1 to $7 \mathrm{dpi}$ in both treatments, but the combined treatment had lower ET production (Figure 5a). It was also suggested that combined Si and SA treatment in the present study had synergistic effects on reducing ET release. The $A C C O$ transcripts in single and combination treatments were dramatically down-regulated from 3 dpi to $7 \mathrm{dpi}$ (Figure $6 \mathrm{~h}$ ). Hence, these findings combined with previous studies suggested that in combination treatments, the significant decrease of ET production may be more helpful to delay the progression of the necrotrophic phase and the appearance of 
symptoms, which could partly explain the synergistic effects of Si and SA on the control of tomato bacterial wilt. ET signaling components such as ERF1 are involved in the regulation of cell death and defense responses; ERF1 activation is essential for ET and JA signaling pathways [94]. TSRF1-overexpressing plants exhibited increased expression of $P R$ genes, and enhanced resistance to R. solanacearum infection [8]. The JERF3 is a marker for ET and JA pathway [8]. Our results showed that the TSRF1 (Figure 6g) and JERF3 (Figure 6j) transcripts in single and combination treatments were activated considerably in the early stage of infection with $R$. solanacearum. The ERF1 transcripts in single and combination treatments were continuously up-regulated (Figure 6i). The LOX is known as the JAmediated defense marker gene [88]. Our previous soil culture experiment found that the DEG encoding LOX was upregulated, and the LOX activity of the $+\mathrm{Si}$ plants significantly increased linearly with inoculation time [9]. In this study, LOX enzyme activities (Figure 4d) and mRNA expression (Figure 6c) were significantly decreased in single and combination treatments, which is inconsistent with our previous soil culture study [9]. Though there is an extensive antagonism between SA-mediated and JA/ET-mediated defense signaling pathways [100], based on our data, it was suggested that ET and JA signaling pathways may also involve the synergistic effects of Si and SA on the control of tomato bacterial wilt. LOX activity was enhanced by water stress and mechanical damage, and its activity was always reported to be associated with lipid peroxidation damage of cell membrane [22]. Our results imply that single and combined application of Si and SA may inhibit the gene expression and activity of LOX, alleviating the membrane lipid peroxidation damage of plant cell membrane, thereby conferring resistance to $R$. solanacearum.

$\mathrm{Si}$ has been reported as systemic acquired resistance (SAR) activators [101]. In the SAR state, plants are primed to more quickly and more effectively activate defense responses to cope with pathogen attack [102]. SA accumulation is essential for the expression of PR proteins and for resistance during SAR $[30,103,104]$. SA is involved in immunity against biotrophic and hemibiotrophic pathogens [105]. In the present study, SA content was significantly increased from 1 to $7 \mathrm{dpi}$ in the single and combination treatments (Figure $5 \mathrm{~b}$ ), and the SA content decreased from $3 \mathrm{dpi}$ to $7 \mathrm{dpi}$ in the control plants (Figure 5b), which is partly inconsistent with our previous soil-pot culture experiment [9]. As mentioned above, $R$. solanacearum is a hemibiotrophic bacterial pathogen [96]. Thus, our results suggest that the timing of the transition from the hemibiotrophic phase to the necrotrophic phase of $R$. solanacearum was delayed considerably in the single and combination treatments compared to plants in the control group. Notably, pre-treatments with SA did not significantly alter the level of endogenous SA (Figure 5b), it was suggested that the defense response induced by exogenous SA may be weakly associated with the level of endogenous SA, which was consistent with a previous study [106]. SA has been shown that it can affect susceptibility of plants to various pathogens $[107,108]$. It is reported that the reduction of the host plant's internal SA level is the strategy of Colletotrichum gloeosporioides for successful infection in strawberry [109]. Our results indicated that the reduced levels of endogenous SA in the control plants were probably associated with increased susceptibility to $R$. solanacearum in hydroponic tomato plants.

The PR1 known as the SAR- and SA-signaling marker gene [102]. Our results showed that the transcript levels for $P R 1$ were significantly elevated in the early stage of infection (Figure 6f). PALs, sometimes classified as PR proteins, are involved in the biosynthesis of SA, phenolpropanoids, phytoalexins, and lignin [22]. The PAL transcripts were significantly induced in the single and combination treatments at $3 \mathrm{dpi}$, and the $P A L$ transcripts were significantly induced for the Si+SA treatment at $7 \mathrm{dpi}$ in comparison to that of the SA treatment (Figure 6a), and this indicated that combined Si and SA treatment in the present study had synergistic effects on the expression levels of $P A L$ transcripts. The up-regulation of PR1 and PAL genes and the increase of SA content suggested the induction of SAR- and SA-signaling pathways. Under hypertonic conditions, the SA pathway and SA-dependent SAR pathway may be involved in the synergistic effects of Si and SA on the control of tomato bacterial wilt. 
The active defense phytohormone SA serves as a long-distance signal for SAR. SAR signal must be transported from infected to uninfected tissue [103,104]. However, SA is not the mobile signal for SAR, since NahG mutant rootstocks, which are unable to accumulate SA, were still able to transmit a signal for SAR to wild-type scions [104]. Methyl salicylate (MeSA) is a critical mobile signal for plant SAR and considered to be the long-distance signaling molecule [28]. SABP2 mediates the hydrolysis of MeSA to SA, it is essential for the establishment of SAR, since SAR is completely abolished in SABP2-silenced tobacco [28]. Furthermore, it is reported that $R$. solanacearum is able to suppress the SA defense pathway of Arabidopsis [110]. In our previous study, it was reported that under soil culture conditions, the $S A B P 2$ transcripts were continuously downregulated in Si-treated plants [9]. Remarkably, in this study, $S A B P 2$ gene expression was strongly suppressed in both treatments, but the degree of suppression in the $\mathrm{Si}+\mathrm{SA}$ plants was significantly lower than that in other treatments (Figure 6k). Under the hypertonic condition, our findings indicated that the combination of Si and SA might have significant synergistic effects in partially alleviating the inhibitory effects of $R$. solanacearum infection on the transduction of the long-distance SAR signal, and also suggested that SA- and SAR-independent pathways may be involved in the synergistic effects of Si and SA on the control of tomato bacterial wilt.

The expression patterns of PAL, POD, ACCO, ERF1 and JERF3 demonstrated that patterns between the treated plants and the control plants were almost mirror image (Figure $6 \mathrm{a}, \mathrm{b}, \mathrm{h}-\mathrm{j}$ ), which is also inconsistent with the results of our previous soil culture experiment [9]. We suggested that the timing and magnitude of expression of these genes may have importantly contributed to the synergistic effects of Si and SA on the control of bacterial wilt in hydroponically grown tomato plants. On the basis of the data presented above, we speculated that the time-course and magnitude of Si-mediated defense response to $R$. solanacearum in tomato plants may differ considerably between hydroponic and soil systems. Moreover, the results presented here show that the root systems may also play an important role in defense responses to $R$. solanacearum in tomato.

Salicylic acid is widely accepted as a complex modulator of plant defense responses [108], we proposed that Si may also act as a modulator influencing the timing and/or extent of plant defense responses in the tomato- $R$. solanacearum pathosystem. Meanwhile, we proposed that Si may interact with SA in tomato- $R$. solanacearum interaction. Our data together suggested that $\mathrm{Si}$ in combination with SA may influence the timing and/or extent of plant defense responses in this interaction system, thereby enhancing the resistance of tomato plants to bacterial wilt. It was also suggested that the combined application of $\mathrm{Si}$ and SA may significantly alleviate the adverse effects (e.g., water-deficit and oxidative stress) caused by infection in hydroponically grown tomato plants through improving root morphology, altering sucrose-metabolizing enzyme activities and sucrose levels, activating antioxidant enzymes, and suppressing ET production, thereby increasing the tolerance of tomato plants to bacterial wilt. However, the exact mechanisms of the synergistic effects of Si and SA can be more complex because of the fact that SA- and Si-mediated defense responses are highly regulated through a complicated network.

\section{Conclusions}

In summary, the present study highlights that the combined application of $2.0 \mathrm{mM}$ potassium silicate $\left(\mathrm{K}_{2} \mathrm{SiO}_{3}\right)$ and $0.5 \mathrm{mM} \mathrm{SA}$ significantly enhanced the resistance of hydroponically grown tomato plants against $R$. solanacearum infection. The possible mechanism of the synergistic effects of $\mathrm{Si}$ and $\mathrm{SA}$ against tomato bacterial wilt was mainly by improving root morphological traits (root length, surface area, average diameter, and volume), enhancing antioxidant enzyme activity, and inhibiting ET production. Si treatment combined with SA could be an environmentally friendly alternative to control bacterial wilt disease of tomato plants. 
Supplementary Materials: The following are available online at https:/ / www.mdpi.com/article/10 .3390/su13073750/s1, Table S1: MS/MS parameters for determination of phytohormones; Table S2: List of primers used for qRT-PCR experiments.

Author Contributions: N.-H.J. conceived and designed the ideas and wrote the manuscript; N.-H.J. conducted the experiments, performed the analyses, and collected the data; S.-H.Z. helped in statistic evaluations; N.-H.J. and S.-H.Z. read and edited the manuscript. All authors have read and agreed to the published version of the manuscript.

Funding: This study was financially supported by grants from the Scientific Research Fund of Yunnan Provincial Education Department (2020J0759).

Institutional Review Board Statement: Not applicable.

Informed Consent Statement: Not applicable.

Data Availability Statement: The data presented in this study are available on request from the corresponding author.

Conflicts of Interest: The authors declare no conflict of interest.

\section{References}

1. The Tomato Genome Consortium. The tomato genome sequence provides insights into fleshy fruit evolution. Nature 2012, 485, 635-641. [CrossRef]

2. Genin, S. Molecular traits controlling host range and adaptation to plants in Ralstonia solanacearum. New Phytol. 2010, 187, 920-928. [CrossRef]

3. Dannon, E.A.; Wydra, K. Interaction between silicon amendment, bacterial wilt development and phenotype of Ralstonia solanacearum in tomato genotypes. Physiol. Mol. Plant Pathol. 2004, 64, 233-243. [CrossRef]

4. Chen, Y.; Liu, M.; Wang, L.; Lin, W.; Fan, X.; Cai, K. Proteomic characterization of silicon-mediated resistance against Ralstonia solanacearum in tomato. Plant Soil 2015, 387, 425-440. [CrossRef]

5. $\quad$ Singh, S.; Gautam, R.K.; Singh, D.R.; Sharma, T.V.R.S.; Sakthivel, K.; Roy, S.D. Genetic approaches for mitigating losses caused by bacterial wilt of tomato in tropical islands. Eur. J. Plant Pathol. 2015, 143, 205-221. [CrossRef]

6. Pradhanang, P.M.; Momol, M.T.; Olson, S.M.; Jones, J.B. Effects of Plant Essential Oils on Ralstonia solanacearum Population Density and Bacterial Wilt Incidence in Tomato. Plant Dis. 2003, 87, 423-427. [CrossRef]

7. Messiha, N.A.S.; Van Diepeningen, A.D.; Wenneker, M.; Van Beuningen, A.R.; Janse, J.D.; Coenen, T.G.C.; Termorshuizen, A.J.; Van Bruggen, A.H.C.; Blok, W.J. Biological Soil Disinfestation (BSD), a new control method for potato brown rot, caused by Ralstonia solanacearum race 3 biovar 2. Eur. J. Plant Pathol. 2007, 117, 403-415. [CrossRef]

8. Ghareeb, H.; Bozsó, Z.; Ott, P.G.; Repenning, C.; Stahl, F.; Wydra, K. Transcriptome of silicon-induced resistance against Ralstonia solanacearum in the silicon non-accumulator tomato implicates priming effect. Physiol. Mol. Plant Pathol. 2011, 75, 83-89. [CrossRef]

9. Jiang, N.; Fan, X.; Lin, W.; Wang, G.; Cai, K. Transcriptome Analysis Reveals New Insights into the Bacterial Wilt Resistance Mechanism Mediated by Silicon in Tomato. Int. J. Mol. Sci. 2019, 20, 761. [CrossRef]

10. Epstein, E. The anomaly of silicon in plant biology. Proc. Natl. Acad. Sci. USA 1994, 91, 11-17. [CrossRef]

11. Sheng, H.; Chen, S. Plant silicon-cell wall complexes: Identification, model of covalent bond formation and biofunction. Plant Physiol. Biochem. 2020, 155, 13-19. [CrossRef]

12. Jonas, V.B.; David, D.V.; Höfte, M. Towards establishing broad-spectrum disease resistance in plants: Silicon leads the way. J. Exp. Bot. 2013, 64, 1281-1293.

13. Vivancos, J.; Labbé, C.; Menzies, J.G.; Bélanger, R.R. Silicon-mediated resistance of Arabidopsis against powdery mildew involves mechanisms other than the salicylic acid (SA)-dependent defence pathway. Mol. Plant Pathol. 2014, 16, 572-582. [CrossRef]

14. Chain, F.; Côté-Beaulieu, C.; Belzile, F.; Menzies, J.G.; Bélanger, R.R. A Comprehensive Transcriptomic Analysis of the Effect of Silicon on Wheat Plants Under Control and Pathogen Stress Conditions. Mol. Plant-Microbe Interact. 2009, 22, 1323-1330. [CrossRef]

15. Lux, A.; Lukačová, Z.; Vaculík, M.; Švubová, R.; Kohanová, J.; Soukup, M.; Martinka, M.; Bokor, B. Silicification of Root Tissues. Plants 2020, 9, 111. [CrossRef]

16. Fawe, A.; Abou-Zaid, M.; Menzies, J.G.; Bélanger, R.R. Silicon-Mediated Accumulation of Flavonoid Phytoalexins in Cucumber. Phytopathology 1998, 88, 396-401. [CrossRef] [PubMed]

17. Kiirika, L.M.; Stahl, F.; Wydra, K. Phenotypic and molecular characterization of resistance induction by single and combined application of chitosan and silicon in tomato against Ralstonia solanacearum. Physiol. Mol. Plant Pathol. 2013, 81, 1-12. [CrossRef]

18. Shetty, R.; Fretté, X.; Jensen, B.; Shetty, N.P.; Jensen, J.D.; Jørgensen, H.J.L.; Newman, M.-A.; Christensen, L.P. Silicon-Induced Changes in Antifungal Phenolic Acids, Flavonoids, and Key Phenylpropanoid Pathway Genes during the Interaction between Miniature Roses and the Biotrophic Pathogen Podosphaera pannosa. Plant Physiol. 2011, 157, 2194-2205. [CrossRef] [PubMed] 
19. Bockhaven, J.V.; Spíchal, L.; Novák, O.; Strnad, M.; Asano, T.; Kikuchi, S.; Höfte, M.; Vleesschauwer, D.D. Silicon induces resistance to the brown spot fungus Cochliobolus miyabeanus by preventing the pathogen from hijacking the rice ethylene pathway. New Phytol. 2015, 206, 761-773. [CrossRef]

20. Kurabachew, H.; Stahl, F.; Wydra, K. Global gene expression of rhizobacteria-silicon mediated induced systemic resistance in tomato (Solanum lycopersicum) against Ralstonia solanacearum. Physiol. Mol. Plant Pathol. 2013, 84, 44-52. [CrossRef]

21. Rasoolizadeh, A.; Labbé, C.; Sonah, H.; Deshmukh, R.K.; Belzile, F.; Menzies, J.G.; Bélanger, R.R. Silicon protects soybean plants against Phytophthora sojae by interfering with effector-receptor expression. BMC Plant Biol. 2018, 18, 97. [CrossRef] [PubMed]

22. Kurabachew, H.; Wydra, K. Induction of systemic resistance and defense-related enzymes after elicitation of resistance by rhizobacteria and silicon application against Ralstonia solanacearum in tomato (Solanum lycopersicum). Crop. Prot. 2014, 57, 1-7. [CrossRef]

23. Lin, W.-P.; Jiang, N.-H.; Peng, L.; Fan, X.-Y.; Gao, Y.; Wang, G.-P.; Cai, K.-Z. Silicon impacts on soil microflora under Ralstonia Solanacearum inoculation. J. Integr. Agric. 2020, 19, 251-264. [CrossRef]

24. Wang, L.; Cai, K.; Chen, Y.; Wang, G. Silicon-Mediated Tomato Resistance Against Ralstonia solanacearum is Associated with Modification of Soil Microbial Community Structure and Activity. Biol. Trace Elem. Res. 2013, 152, 275-283. [CrossRef] [PubMed]

25. Wang, M.; Gao, L.; Dong, S.; Sun, Y.; Shen, Q.; Guo, S. Role of Silicon on Plant-Pathogen Interactions. Front. Plant Sci. 2017, 8, 701. [CrossRef]

26. French, E.; Kim, B.-S.; Rivera-Zuluaga, K.; Iyer-Pascuzzi, A.S. Whole Root Transcriptomic Analysis Suggests a Role for Auxin Pathways in Resistance to Ralstonia solanacearum in Tomato. Mol. Plant-Microbe Interact. 2018, 31, 432-444. [CrossRef] [PubMed]

27. Fan, X.-Y.; Lin, W.-P.; Liu, R.; Jiang, N.-H.; Cai, K.-Z. Physiological response and phenolic metabolism in tomato (Solanum lycopersicum) mediated by silicon under Ralstonia solanacearum infection. J. Integr. Agric. 2018, 17, 2160-2171. [CrossRef]

28. Vlot, A.C.; Liu, P.-P.; Cameron, R.K.; Park, S.-W.; Yang, Y.; Kumar, D.; Zhou, F.; Padukkavidana, T.; Gustafsson, C.; Pichersky, E.; et al. Identification of likely orthologs of tobacco salicylic acid-binding protein 2 and their role in systemic acquired resistance inArabidopsis thaliana. Plant J. 2008, 56, 445-456. [CrossRef]

29. Lowe-Power, T.M.; Jacobs, J.M.; Ailloud, F.; Fochs, B.; Prior, P.; Allen, C. Degradation of the plant defense signal salicylic acid protects Ralstonia solanacearum from toxicity and enhances virulence on tobacco. MBio 2016, 7, e00656-16. [CrossRef]

30. Chamnongpol, S.; Willekens, H.; Moeder, W.; Langebartels, C.; Sandermann, H., Jr.; Van Montagu, M.; Inzé, D.; Van Camp, W. Defense activation and enhanced pathogen tolerance induced by $\mathrm{H} 2 \mathrm{O} 2$ in transgenic tobacco. Proc. Natl. Acad. Sci. USA 1998, 95, 5818-5823. [CrossRef]

31. Mandal, S.; Mallick, N.; Mitra, A. Salicylic acid-induced resistance to Fusarium oxysporum f. sp. lycopersici in tomato. Plant Physiol. Biochem. 2009, 47, 642-649. [CrossRef]

32. Afroz, A.; Khan, M.R.; Ahsan, N.; Komatsu, S. Comparative proteomic analysis of bacterial wilt susceptible and resistant tomato cultivars. Peptides 2009, 30, 1600-1607. [CrossRef] [PubMed]

33. Narasimhamurthy, K.; Soumya, K.; Udayashankar, A.; Srinivas, C.; Niranjana, S. Elicitation of innate immunity in tomato by salicylic acid and Amomum nilgiricum against Ralstonia solanacearum. Biocatal. Agric. Biotechnol. 2019, 22, 101414. [CrossRef]

34. Chen, Y.Y.; Lin, Y.M.; Chao, T.C.; Wang, J.F.; Liu, A.C.; Ho, F.I.; Cheng, C.P. Virus-induced gene silencing reveals the involvement of ethylene-, salicylic acid- and mitogen-activated protein kinase-related defense pathways in the resistance of tomato to bacterial wilt. Physiol. Plant. 2009, 136, 324-335. [CrossRef] [PubMed]

35. Jacobs, J.M.; Babujee, L.; Meng, F.; Milling, A.; Allen, C. The In Planta Transcriptome of Ralstonia solanacearum: Conserved Physiological and Virulence Strategies during Bacterial Wilt of Tomato. mBio 2012, 3, e00114-12. [CrossRef]

36. Yu, J.Q.; Lee, K.S.; Matsui, Y. Effect of the addition of activated charcoal to the nutrient solution on the growth of tomato in hydroponic culture. Soil Sci. Plant Nutr. 1993, 39, 13-22. [CrossRef]

37. Sapkota, S.; Sapkota, S.; Liu, Z. Effects of nutrient composition and lettuce cultivar on crop production in hydroponic culture. Horticulturae 2019, 5, 72. [CrossRef]

38. Moon, K.-B.; Park, J.-S.; Park, Y.-I.; Song, I.-J.; Lee, H.-J.; Cho, H.S.; Jeon, J.-H.; Kim, H.-S. Park Development of Systems for the Production of Plant-Derived Biopharmaceuticals. Plants 2019, 9, 30. [CrossRef]

39. Shimizu, K.; Matsuda, Y.; Nonomura, T.; Ikeda, H.; Tamura, N.; Kusakari, S.; Kimbara, J.; Toyoda, H. Dual protection of hydroponic tomatoes from rhizosphere pathogens Ralstonia solanacearum and Fusarium oxysporum f.sp. radicis-lycopersici and airborne conidia of Oidium neolycopersici with an ozone-generative electrostatic spore precipitator. Plant Pathol. 2007, 56, 987-997. [CrossRef]

40. Picot, A.; Cobo-Díaz, J.F.; Pawtowski, A.; Donot, C.; Legrand, F.; Le Floch, G.; Déniel, F. Water Microbiota in Greenhouses With Soilless Cultures of Tomato by Metabarcoding and Culture-Dependent Approaches. Front. Microbiol. 2020, 11, 1354. [CrossRef]

41. Van Elsas, J.D.; Kastelein, P.; De Vries, P.M.; Van Overbeek, L.S. Effects of ecological factors on the survival and physiology of Ralstonia solanacearum bv. 2 in irrigation water. Can. J. Microbiol. 2001, 47, 842-854. [CrossRef]

42. Sui, X.C. The Endemic Factors of Tomato Bacterial Wilt in Soilless Culture System and Prevention Approache by Micro-Ecological Environment. Master's Thesis, Nanjing Agricultural University, Nanjing, China, 2007.

43. Tavakkoli, E.; Rengasamy, P.; McDonald, G.K. The response of barley to salinity stress differs between hydroponic and soil systems. Funct. Plant Biol. 2010, 37, 621-633. [CrossRef]

44. Chen, L.; Yang, S.; Liu, Y.; Mo, M.; Guan, X.; Huang, L.; Sun, C.; Yang, S.T.; Chang, X.L. Toxicity of graphene oxide to naked oats (Avena satival.) in hydroponic and soil cultures. RSC Adv. 2018, 8, 15336-15343. [CrossRef] 
45. Ahsan, M.; Wright, D. Wheat Varietal Behavior in Hydroponic and Soil Culture Under Saline Conditions. Pak. J. Biol. Sci. 1998, 1, 318-320. [CrossRef]

46. Holubík, O.; Vaněk, A.; Mihaljevič, M.; Vejvodová, K. Higher Tl bioaccessibility in white mustard (hyper-accumulator) grown under the soil than hydroponic conditions: A key factor for the phytoextraction use. J. Environ. Manag. 2020, 255, 109880. [CrossRef] [PubMed]

47. Cai, K.; Gao, D.; Luo, S.; Zeng, R.; Yang, J.; Zhu, X. Physiological and cytological mechanisms of silicon-induced resistance in rice against blast disease. Physiol. Plant. 2008, 134, 324-333. [CrossRef]

48. El Ghaouth, A.; Wilson, C.L.; Wisniewski, M. Control of Postharvest Decay of Apple Fruit with Candida saitoana and Induction of Defense Responses. Phytopathology 2003, 93, 344-348. [CrossRef]

49. Balibrea, M.E.; Dell'Amico, J.; Bolarín, M.C.; Pérez-Alfocea, F. Carbon partitioning and sucrose metabolism in tomato plants growing under salinity. Physiol. Plant. 2000, 110, 503-511. [CrossRef]

50. DallAgnol, L.J.; Rodrigues, F.A.; Pascholati, S.F.; Fortunato, A.A.; Camargo, L.E.A. Comparison of root and foliar applications of potassium silicate in potentiating post-infection defences of melon against powdery mildew. Plant Pathol. 2015, 64, 1085-1093. [CrossRef]

51. Livak, K.J.; Schmittgen, T.D. Analysis of relative gene expression data using real-time quantitative PCR and the 2- $\triangle \triangle \mathrm{Ct}$ method. Methods 2012, 25, 402-408. [CrossRef] [PubMed]

52. Saile, E.; McGarvey, J.A.; Schell, M.A.; Denny, T.P. Role of Extracellular Polysaccharide and Endoglucanase in Root Invasion and Colonization of Tomato Plants by Ralstonia solanacearum. Phytopathology 1997, 87, 1264-1271. [CrossRef]

53. Ailloud, F.; Lowe, T.M.; Robène, I.; Cruveiller, S.; Allen, C.; Prior, P. In planta comparative transcriptomics of host-adapted strains of Ralstonia solanacearum. PeerJ 2016, 4, e1549. [CrossRef] [PubMed]

54. Nikolic, M.; Nikolic, N.; Liang, Y.; Kirkby, E.A.; Römheld, V. Germanium-68 as an Adequate Tracer for Silicon Transport in Plants. Characterization of Silicon Uptake in Different Crop Species. Plant Physiol. 2007, 143, 495-503. [CrossRef]

55. Sofo, A.; Vitti, A.; Nuzzaci, M.; Tataranni, G.; Scopa, A.; Vangronsveld, J.; Remans, T.; Falasca, G.; Altamura, M.M.; Degola, F.; et al. Correlation between hormonal homeostasis and morphogenic responses in Arabidopsis thaliana seedlings growing in a $\mathrm{Cd} / \mathrm{Cu} / \mathrm{Zn}$ multi-pollution context. Physiol. Plant. 2013, 149, 487-498. [CrossRef] [PubMed]

56. Vitti, A.; Nuzzaci, M.; Scopa, A.; Tataranni, G.; Remans, T.; Vangronsveld, J.; Sofo, A. Auxin and Cytokinin Metabolism and Root Morphological Modifications in Arabidopsis thaliana Seedlings Infected with Cucumber mosaic virus (CMV) or Exposed to Cadmium. Int. J. Mol. Sci. 2013, 14, 6889-6902. [CrossRef] [PubMed]

57. Kim, Y.-H.; Khan, A.L.; Lee, I.-J. Silicon: A duo synergy for regulating crop growth and hormonal signaling under abiotic stress conditions. Crit. Rev. Biotechnol. 2016, 36, 1099-1109. [CrossRef] [PubMed]

58. Abozeid, A.; Ying, Z.; Lin, Y.; Liu, J.; Zhang, Z.; Tang, Z. Ethylene improves root system development under cadmium stress by modulating superoxide anion concentration in Aarabidopsis thaliana. Front. Plant Sci. 2017, 8, 253. [CrossRef] [PubMed]

59. Castañeda, V.; de la Peña, M.; Azcárate, L.; Aranjuelo, I.; Gonzalez, E.M. Functional analysis of the taproot and fibrous roots of Medicago truncatula: Sucrose and proline catabolism primary response to water deficit. Agric. Water Manag. 2019, 216, 473-483. [CrossRef]

60. Dodds, P.N.; Rathjen, J.P. Plant immunity: Towards an integrated view of plant-pathogen interactions. Nat. Rev. Genet. 2010, 11, 539-548. [CrossRef]

61. Asthir, B.; Rai, P.K.; Bains, N.S.; Sohu, V.S. Genotypic Variation for High Temperature Tolerance in Relation to Carbon Partitioning and Grain Sink Activity in Wheat. Am. J. Plant Sci. 2012, 3, 381-390. [CrossRef]

62. Kou, J.; Wei, Y.; He, X.; Xu, J.; Xu, F.; Shao, X. Infection of post-harvest peaches by Monilinia fructicola accelerates sucrose decomposition and stimulates the Embden-Meyerhof-Parnas pathway. Hortic. Res. 2018, 5, 1-9. [CrossRef] [PubMed]

63. Zhao, Q.; Chen, W.; Bian, J.; Xie, H.; Li, Y.; Xu, C.; Ma, J.; Guo, S.; Chen, J.; Cai, X.; et al. Proteomics and Phosphoproteomics of Heat Stress-Responsive Mechanisms in Spinach. Front. Plant Sci. 2018, 9, 800. [CrossRef] [PubMed]

64. Xing, X.H.; Xui, Z.J.; Qi, Y.J.; Wang, X.J.; Sun, D.L.; Bian, N.F.; Wang, X. Effect of exogenous $\alpha$-naphthaleneacetic acid on carbon metabolism of soybean under drought stress at flowering stage. Ying Yong Sheng Tai Xue Bao J. Appl. Ecol. 2018, 29, $1215-1224$.

65. Su, Y.; Li, T.-L.; Li, N.; Yang, F.-J.; Lu, S.-W. Effects of salicylic acid on sucrose metabolism of tomato seedlings under NaCl stress. J. Appl. Ecol. 2009, 20, 1525.

66. Lu, S.W.; Li, T.L.; Jiang, J. Tomato key sucrose metabolizing enzyme activities and gene expression under NaCI and PEG Iso-osmotic stresses. Agric. Sci. China 2009, 8, 1046-1052. [CrossRef]

67. Abdelaal, K.A.A.; Mazrou, Y.S.; Hafez, Y.M. Silicon Foliar Application Mitigates Salt Stress in Sweet Pepper Plants by Enhancing Water Status, Photosynthesis, Antioxidant Enzyme Activity and Fruit Yield. Plants 2020, 9, 733. [CrossRef]

68. Jun, Y.; Jun, Z.; Tao, W.; Zhao, M.L.; Rong, L.; Pim, G.; Huang, Q.W.; Bai, Y.; Vivanco, J.M.; Kowalchuk, G.A.; et al. Root exudates drive the soil-borne legacy of aboveground pathogen infection. Microbiome 2018, 6, 156.

69. Saldajeno, M.G.B.; Naznin, H.A.; Elsharkawy, M.M.; Shimizu, M.; Hyakumachi, M. Enhanced resistance of plants to disease using Trichoderma spp. In Biotechnology and Biology of Trichoderma; Gupta, V.K., Schmoll, M., Herrera-Estrella, A., Upadhyay, R.S., Druzhinina, I., Tuohy, M., Eds.; Elsevier Science B.V.: Amsterdam, The Netherlands, 2014; pp. 477-494.

70. Kwak, M.J.; Kong, H.G.; Choi, K.; Kwon, S.K.; Kim, J.F. Rhizosphere microbiome structure alters to enable wilt resistance in tomato. Nat. Biotechnol. 2018, 36, 1117. [CrossRef] 
71. Gu, Y.; Wang, X.; Yang, T.; Friman, V.; Geisen, S.; Wei, Z.; Xu, Y.; Jousset, A.; Shen, Q. Chemical structure predicts the effect of plant-derived low-molecular weight compounds on soil microbiome structure and pathogen suppression. Funct. Ecol. 2020, 34, 2158-2169. [CrossRef]

72. Atkinson, M.M.; Baker, C.J. Alteration of plasmalemma sucrose transport in Phaseolus vulgaris by Pseudomonas syringae pv. syringae and its association with $\mathrm{K}+/ \mathrm{H}+$ exchange. Phytopathology 1987, 77, 1573-1578. [CrossRef]

73. Qamar, A.; Mysore, K.S.; Senthil-Kumar, M. Role of proline and pyrroline-5-carboxylate metabolism in plant defense against invading pathogens. Front. Plant Sci. 2015, 6, 503. [CrossRef]

74. Wind, J.; Smeekens, S.; Hanson, J. Sucrose: Metabolite and signaling molecule. Phytochemistry 2010, 71, 1610-1614. [CrossRef]

75. Gómez-Ariza, J.; Campo, S.; Rufat, M.; Estopà, M.; Messeguer, J.; Segundo, B.S.; Coca, M. Sucrose-Mediated Priming of Plant Defense Responses and Broad-Spectrum Disease Resistance by Overexpression of the Maize Pathogenesis-Related PRms Protein in Rice Plants. Mol. Plant-Microbe Interact. 2007, 20, 832-842. [CrossRef]

76. Duan, L.; Liu, H.; Li, X.; Xiao, J.; Wang, S. Multiple phytohormones and phytoalexins are involved in disease resistance to Magnaporthe oryzae invaded from roots in rice. Physiol. Plant. 2014, 152, 486-500. [CrossRef] [PubMed]

77. Nikraftar, F.; Taheri, P.; Rastegar, M.F.; Tarighi, S. Tomato partial resistance to Rhizoctonia solani involves antioxidative defense mechanisms. Physiol. Mol. Plant Pathol. 2013, 81, 74-83. [CrossRef]

78. Ma, Q.-H.; Zhu, H.-H.; Qiao, M.-Y. Contribution of both lignin content and sinapyl monomer to disease resistance in tobacco. Plant Pathol. 2017, 67, 642-650. [CrossRef]

79. Chezem, W.R.; Memon, A.; Li, F.-S.; Weng, J.-K.; Clay, N.K. SG2-Type R2R3-MYB Transcription Factor MYB15 Controls DefenseInduced Lignification and Basal Immunity in Arabidopsis. Plant Cell 2017, 29, 1907-1926. [CrossRef]

80. Wang, Y.; Zhang, Y. Salicylic acid induces the accumulation of defense-related enzymes in Whangkeumbae pear and protects from pear black spot. Front. Agric. China 2010, 4, 215-219. [CrossRef]

81. Jendoubi, W.; Harbaoui, K.; Hamada, W. Salicylic acid-induced resistance against Fusarium oxysporumf.s.pradicis lycopercisi in hydroponic grown tomato plants. J. New Sci. 2015, 21, 985-995.

82. Mandal, S.; Kar, I.; Mukherjee, A.K.; Acharya, P. Elicitor-induced defense responses in Solanum lycopersicum against Ralstonia solanacearum. Sci. World J. 2013, 2013, 561056. [CrossRef]

83. Rais, A.; Jabeen, Z.; Shair, F.; Hafeez, F.Y.; Hassan, M.N. Bacillus spp., a bio-control agent enhances the activity of antioxidant defense enzymes in rice against Pyricularia oryzae. PLoS ONE 2017, 12, e0187412. [CrossRef] [PubMed]

84. Durner, J.; Klessig, D.F. Salicylic Acid Is a Modulator of Tobacco and Mammalian Catalases. J. Biol. Chem. 1996, 271 , 28492-28501. [CrossRef]

85. Liu, Q.; Li, K.; Guo, X.; Ma, L.; Guo, Y.; Liu, Z. Developmental characteristics of grapevine seedlings root border cells and their response to $\rho$-hydroxybenzoic acid. Plant Soil 2019, 443, 199-218. [CrossRef]

86. Heil, M.; Bostock, R.M. Induced systemic resistance (ISR) against pathogens in the context of induced plant defences. Ann. Bot. 2002, 89, 503-512. [CrossRef] [PubMed]

87. Dana, M.D.L.M.; Pintor-Toro, J.A.; Cubero, B. Transgenic Tobacco Plants Overexpressing Chitinases of Fungal Origin Show Enhanced Resistance to Biotic and Abiotic Stress Agents. Plant Physiol. 2006, 142, 722-730. [CrossRef]

88. Baichoo, Z.; Jaufeerally-Fakim, Y. Ralstonia solanacearum upregulates marker genes of the salicylic acid and ethylene signaling pathways but not those of the jasmonic acid pathway in leaflets of Solanum lines during early stage of infection. Eur. J. Plant Pathol. 2016, 147, 615-625. [CrossRef]

89. Ishihara, T.; Mitsuhara, I.; Takahashi, H.; Nakaho, K. Transcriptome Analysis of Quantitative Resistance-Specific Response upon Ralstonia solanacearum Infection in Tomato. PLoS ONE 2012, 7, e46763. [CrossRef]

90. Chen, S.-C.; Liu, A.-R.; Zou, Z.-R. Overexpression of glucanase gene and defensin gene in transgenic tomato enhances resistance to Ralstonia solanacearum. Russ. J. Plant Physiol. 2006, 53, 671-677. [CrossRef]

91. Pieterse, C.M.; Van Der Does, D.; Zamioudis, C.; Leon-Reyes, A.; Van Wees, S.C. Hormonal Modulation of Plant Immunity. Annu. Rev. Cell Dev. Biol. 2012, 28, 489-521. [CrossRef]

92. Mengiste, T. Plant Immunity to Necrotrophs. Annu. Rev. Phytopathol. 2012, 50, 267-294. [CrossRef]

93. Verma, V.; Ravindran, P.; Kumar, P.P. Plant hormone-mediated regulation of stress responses. BMC Plant Biol. 2016, 16, 86. [CrossRef]

94. Wang, H.; Lin, J.; Chang, Y.; Jiang, C.Z. Comparative transcriptomic analysis reveals that ethylene $/ \mathrm{H}_{2} \mathrm{O}_{2}$-mediated hypersensitive response and programmed cell death determine the compatible interaction of sand pear Andalternaria alternate. Front. Plant Sci. 2017, 8, 195. [CrossRef] [PubMed]

95. Pieterse, C.M.J.; Leon-Reyes, A.; Van Der Ent, S.; Van Wees, S.C.M. Networking by small-molecule hormones in plant immunity. Nat. Chem. Biol. 2009, 5, 308-316. [CrossRef] [PubMed]

96. Narancio, R.; Zorrilla, P.; Robello, C.; Gonzalez, M.; Vilaró, F.; Pritsch, C.; Dalla Rizza, M. Insights on gene expression response of a caracterized resistant genotype of Solanum commersonii dun. against Ralstonia olanacearum. Eur. J. Plant Pathol. 2013, 136, 823-835. [CrossRef]

97. Groen, S.C.; Whiteman, N.K. The Evolution of Ethylene Signaling in Plant Chemical Ecology. J. Chem. Ecol. 2014, 40, 700-716. [CrossRef] [PubMed]

98. Babalar, M.; Asghari, M.; Talaei, A.; Khosroshahi, A. Effect of pre- and postharvest salicylic acid treatment on ethylene production, fungal decay and overall quality of Selva strawberry fruit. Food Chem. 2007, 105, 449-453. [CrossRef] 
99. Martínez-Esplá, A.; Serrano, M.; Valero, D.; Martínez-Romero, D.; Castillo, S.; Zapata, P.J. Enhancement of Antioxidant Systems and Storability of Two Plum Cultivars by Preharvest Treatments with Salicylates. Int. J. Mol. Sci. 2017, 18, 1911. [CrossRef] [PubMed]

100. Kunkel, B.N.; Brooks, D.M. Cross talk between signaling pathways in pathogen defense. Curr. Opin. Plant Biol. $2002,5,325-331$. [CrossRef]

101. Fauteux, F.; Rémus-Borel, W.; Menzies, J.G.; Bélanger, R.R. Silicon and plant disease resistance against pathogenic fungi. FEMS Microbiol. Lett 2005, 249, 1-6. [CrossRef]

102. Conrath, U. Systemic acquired resistance. Plant Signal. Behav. 2006, 1, 179-184. [CrossRef]

103. Smith-Becker, J.; Marois, E.; Huguet, E.J.; Midland, S.L.; Sims, J.J.; Keen, N.T. Accumulation of Salicylic Acid and 4Hydroxybenzoic Acid in Phloem Fluids of Cucumber during Systemic Acquired Resistance Is Preceded by a Transient Increase in Phenylalanine Ammonia-Lyase Activity in Petioles and Stems. Plant Physiol. 1998, 116, 231-238. [CrossRef] [PubMed]

104. Kim, H.S.; Delaney, T.P. Over-expression ofTGA5, which encodes a bZIP transcription factor that interacts with NIM1/NPR1, confers SAR-independent resistance inArabidopsis thalianatoPeronospora parasitica. Plant J. 2002, 32, 151-163. [CrossRef]

105. Hosseini, S.; Elfstrand, M.; Heyman, F.; Jensen, D.F.; Karlsson, M. Deciphering common and specific transcriptional immune responses in pea towards the oomycete pathogens Aphanomyces euteiches and Phytophthora pisi. BMC Genom. 2015, 16, 627. [CrossRef] [PubMed]

106. Zhang, Z.H.; Nie, Y.F.; He, L.; Li, Y.F.; Wang, Z.Z. Changes of resistance-related defense enzymes activities and endogenous salicylic acid in rice induced by exogenous salicylic acid. J. Huazhong Agric. Univ. 2010, 29, 541-545.

107. Smith, H.B. Signal transduction in systemic acquired resistance. Plant Cell 2000, 12, 179-181. [CrossRef]

108. Makarova, S.; Makhotenko, A.; Spechenkova, N.; Love, A.J.; Kalinina, N.O.; Taliansky, M. Interactive Responses of Potato (Solanum tuberosum L.) Plants to Heat Stress and Infection With Potato Virus Y. Front. Microbiol. 2018, 9, 2582. [CrossRef] [PubMed]

109. Zhang, Q.-Y.; Zhang, L.-Q.; Song, L.-L.; Duan, K.; Li, N.; Wang, Y.-X.; Gao, Q.-H. The different interactions of Colletotrichum gloeosporioides with two strawberry varieties and the involvement of salicylic acid. Hortic. Res. 2016, 3, 16007. [CrossRef]

110. Chen, Y.; Ren, X.; Zhou, X.; Huang, L.; Yan, L.; Lei, Y.; Liao, B.; Huang, J.; Huang, S.; Wei, W.; et al. Dynamics in the resistant and susceptible peanut (Arachis hypogaea L.) root transcriptome on infection with the Ralstonia solanacearum. BMC Genom. 2014, 15, 1078. [CrossRef] 